Research papers

\title{
Contribution of combined carbohydrates to dissolved and particulate organic carbon after the spring bloom in the northern Bay of Biscay (North-Eastern Atlantic Ocean)
}

\author{
Anja Engel ${ }^{\mathrm{a}, *, 1}$, Jérôme Harlay ${ }^{\mathrm{b}, 2}$, Judith Piontek ${ }^{\mathrm{a}, 1}$, Lei Chou ${ }^{\mathrm{b}}$ \\ a Alfred Wegener Institute (AWI)—Am Handelshafen 12, 27570 Bremerhaven, Germany \\ ${ }^{\mathrm{b}}$ Laboratoire d'Océanographie Chimique et Géochimie des Eaux-Université Libre de Bruxelles (ULB), Belgium ${ }^{3}$
}

\section{A R T I C L E I N F O}

\section{Article history:}

Received 17 June 2011

Received in revised form

22 May 2012

Accepted 28 May 2012

Available online 13 June 2012

\section{Keywords:}

Bay of Biscay

DOC

POC

Combined carbohydrates

TEP

Carbon partitioning

\begin{abstract}
A B S T R A C T
Two cruises were conducted after the diatom spring bloom in the northern Bay of Biscay $(2006,2007)$ to assess the contribution of combined carbohydrates to organic carbon partitioning. Partitioning of total organic carbon (TOC) into particulate organic carbon (POC) and dissolved organic carbon (DOC) differed between the two years, particularly for depths above $60 \mathrm{~m}$, and was related to the vernal development of the system: a post spring-bloom system in 2007, and a more stratified summer system with higher coccolithophore abundance in 2006. In general, contribution of POC to TOC ranged between $4 \%$ and $28 \%$ and decreased with depth. Concentration of high-molecular-weight (HMW; $>1 \mathrm{kDa}$ ) dissolved combined carbohydrates ( $\mathrm{dCCHO}$ ) ranged from 0.6 to $1.4 \mu \mathrm{mol} \mathrm{L}^{-1}$ and contributed between $4 \%$ and $11 \%$ to DOC. Concentration of particulate combined carbohydrates (pCCHO) varied between 0.03 and $1.3 \mu \mathrm{mol} \mathrm{L}^{-1}$. A high contribution of pCCHO to POC was observed in 2007 , i.e. $22-60 \% \mathrm{C}$ compared to $3-10 \% \mathrm{C}$ in 2006 , and coincided with a higher abundance of transparent exopolymer particles (TEP). TEP accounted for $0.4-2.0 \mu \mathrm{mol} \mathrm{C} \mathrm{L}{ }^{-1}$ in 2007 and $0.5-1.5 \mu \mathrm{mol} \mathrm{C} \mathrm{L}{ }^{-1}$ in 2006 . Above $60 \mathrm{~m}$, differences in contribution of TEP-C to POC were most pronounced yielding $15.4 \pm 3.0 \%$ in 2007 compared to relatively low $4.8+1.4 \%$, in 2006 . TEP-C could explain about $60 \%$ in 2007 and about $40 \%$ of pCCHO-C in 2006. Hence, TEP were identified as a substantial component of pCCHO and POC, particularly in the wake of the spring bloom. Molecular composition of $\mathrm{CCHO}$, i.e. HMW-dCCHO + pCCHO, revealed little difference between the years but strong variation over depth. Uronic acids (URA) were identified as a major component of $\mathrm{CCHO}(20-40 \%)$. Our study indicates that the distribution and composition of $\mathrm{CCHO}$ in surface seawater are determined by biogeochemical processes on a seasonal scale. A better knowledge of CCHO cycling and molecular signature has therefore a high potential for a better tracing of carbon dynamics in shelf sea ecosystems.
\end{abstract}

(c) 2012 Elsevier Ltd. All rights reserved.

\section{Introduction}

Spring is the main season of new production of organic carbon in temperate pelagic ecosystems. At this time, the sequential rise and decay of phytoplankton blooms control the accumulation of particulate organic carbon (POC) and of dissolved organic carbon (DOC) in the upper water column (Mann and Lazier, 1991; Hydes et al., 2001), and thereby largely prescribes the ecosystem's

\footnotetext{
* Corresponding author.

E-mail address: aengel@geomar.de (A. Engel).

${ }^{1}$ Present address: Helmholtz Centre for Ocean Research Kiel (GEOMAR), Düsternbrooker Weg 20, D-24105 Kiel, Germany.

2 Present address: Unité d'Océanographie Chimique, Université de Liège (ULg) Institut de Physique (B5), Allée du 6 Août 17 B-4000 Sart-Tilman, Belgium.

${ }^{3}$ Currently renamed as Service de Biogéochimie et Modélisation du Systém Terre.
}

annual net-uptake of carbon dioxide $\left(\mathrm{CO}_{2}\right)$ (Keir et al., 2001). During the early and peak phases of the bloom, the assimilated dissolved inorganic carbon (DIC) is largely partitioned into POC, and removed from the surface ocean by sinking of cells repackaged into larger particles through physical or biological aggregation, e.g. marine snow, fecal pellets. When autotrophic growth becomes limited by depletion of inorganic nutrients, an increasing fraction of organic carbon gets partitioned into DOC (Myklestad, 1977; Biddanda and Benner, 1997; Engel et al., 2004). DOC production is thereby controlled by various processes, such as the extracellular release from plankton cells (Fogg, 1966; Strom et al. 1997; Ogawa et al., 2001), enzymatic solubilisation of particles (Cho and Azam, 1988; Smith et al., 1992), viral lysis (Fuhrmann, 1999) and metazooplankton grazing (Copping and Lorenzen, 1980; Nagata, 2000). Because DOC is the main substrate for microbial uptake (Azam and Hodson, 1977), springtime DOC production also determines the activity of the microbial food web, 
and therefore the recycling and remineralisation of organic matter in the surface ocean (Azam et al., 1983).

Besides the activity of processing microbes, the rates of organic matter turnover in seawater strongly depend on the molecular characteristics of the organic substrates (Arnosti, 2004). In contrast to labile, i.e. readily bio-available, substrates like monomeric sugars and amino acids, and low-molecularweight combined carbohydrates and peptides, displaying turnover times of hours to days, semi-labile and refractory components can accumulate in the water column over months to centuries (Anderson and Williams, 1999; Hansell, 2002; Carlson, 2002). In temperate systems, the seasonally accumulating, surface DOC becomes available for deep export during wintertime mixing and contributes to the biological $\mathrm{CO}_{2}$ pump (Hopkinson and Vallino, 2005; Hansell et al., 2009). The largest characterised fraction of this accumulating DOC are combined carbohydrates (CCHO) with a molecular weight $>1 \mathrm{kDa}$ (Alluwihare et al., 1997; Borch and Kirchman, 1997; Skoog and Benner, 1997; Kirchman et al., 2001), which also represent the largest characterisable pool (50-70\% carbon) of high-molecular-weight (HMW) DOC in general (Benner et al., 1992; Pakulski and Benner, 1994; Benner, 2002; Kaiser and Benner, 2009). Combined by sugar monomers, $\mathrm{CCHO}$ serve as structural components and for energy storage in marine plankton organisms. Combined carbohydrates comprise about $17-40 \%$ of plankton dry weight (Parsons et al., 1983), and 10-30\% of plankton carbon (Suárez and Marañon, 2003), with combined neutral sugars accounting for about $6-10 \%$ of plankton carbon (Kaiser and Benner, 2009). Dissolved CCHO (dCCHO) represent the largest dynamic carbon source in the ocean, i.e. $10-35 \%$ of DOC (Benner et al., 1992).

Within the pool of HMW-dCCHO, combined carbohydrates are principally available for biological consumption, but need to be chopped into smaller subunits ( $600-800 \mathrm{Da}$ ) before they can be taken up by microorganisms (Benz and Bauer, 1988; Weiss et al., 1991). Microbial processing thereby may alter the quality and hence the biological accessibility of the dissolved substrates, leaving behind more refractory compounds (Jiao et al., 2010). Microbial assimilation of dCCHO into biomass leads to a repartitioning of dCCHO into particles. Another way of re-partitioning of HMW-dCCHO into POC is the formation of gel particles, such as transparent exopolymer particles (TEP) (Alldredge et al., 1993; Chin et al., 1998; Engel et al., 2004). The formation of TEP is controlled by aggregation and gelation dynamics (Chin et al., 1998; Engel et al., 2004; Verdugo and Santschi, 2010) and, primarily controlled by the concentration and composition of HMW-dCCHO, as well as by physical factors affecting collision and assembly rates such as turbulence and temperature. Because extracellular release by phytoplankton is a major source of HMWdCCHO, TEP concentration often increases during phytoplankton blooms (Passow, 2002). To date, the quantitative importance of TEP production for DOC-POC partitioning in the field, as well as the role of the molecular CCHO composition for TEP aggregation, are largely unknown. TEP are detected by staining with Alcian Blue, a copper-phtalocyanine dye that binds to acidic, particularly uronic and sulphated sugars (Ramus, 1977). Acidic sugars can combine separate molecules via divalent cation bridging (Ramus, 1977; Alldredge et al., 1993). Acidic sugars are therefore expected to represent a substantial fraction of carbohydrates contained in TEP and to be specifically involved in the TEP formation process (Alldredge et al., 1993; Mopper et al., 1995; Zhou et al., 1998; Passow, 2002). Natural acidic polysaccharides are heteropolysaccharides that contain neutral, amino and acidic sugars, such as glucose, galactose, rhamnose, glucuronic and galacturonic acid and amino sugars, such as glucosamine (Decho, 1990; Leppard, 1995). Acidic polysaccharides have also been suggested to be involved in trace element cycling, i.e. Fe and Zn, or in the removal of the particle reactive tracer ${ }^{234} \mathrm{Th}$ (Quigley et al., 2002; Guo et al., 2002; Steigenberger et al., 2010). Despite their potential importance for biogeochemical cycling and particle dynamics, little information is available on the abundance of acidic polysaccharides in seawater so far. Therewith the dynamics and biological control of particular processes involving acidic sugars, such as TEP formation in marine systems, are largely unknown.

The northern Bay of Biscay is located in the North-Eastern Atlantic Ocean, south of Ireland and west of France. Here, a steep slope separates the abyssal plain from the continental plateau. The Bay of Biscay has been extensively studied since the late 1980s, e.g. within the framework of the Belgian PPS "Global Change" and SPSD2 "Climate" programmes, and the EU OMEX I and II projects. Long-term series of physical, biological and chemical variables are available for model validation, but information on processes determining the seasonal relationship between DOC and POC are scarce. This information, however, is required to better understand the fate of organic carbon during the transition from spring to summer, including consequences for carbon export and microbial ecosystem functioning.

Here, we investigated the concentration and molecular composition of $\mathrm{CCHO}$ and their contribution to carbon partitioning during two consecutive years in the northern Bay of Biscay. The study was part of the 'PElagic cAlcification and export of CarbonatE production in climate change (PEACE)' project that was launched in 2005 to evaluate the role of calcification in climate regulation, production and export processes during coccolithophore blooms.

\section{Materials and methods}

\subsection{Study site and field sampling}

Samples were collected from the research vessel Belgica between $47.42^{\circ} \mathrm{N}, 7.27^{\circ} \mathrm{W}$ and $48.50^{\circ} \mathrm{N}, 8.90^{\circ} \mathrm{W}$ from 31 May to 9 June in 2006 , and between $47.68^{\circ} \mathrm{N}, 8.20^{\circ} \mathrm{W}$ and $51.34^{\circ} \mathrm{N}$, $10.5^{\circ} \mathrm{W}$ from 10 May to 24 May in 2007. Seven stations were sampled in 2006, and 9 stations in 2007 (Fig. 1). A Seabird CTD system, equipped with a 12 Niskin bottles $(10 \mathrm{~L})$ rosette sampler, was used to determine depth profiles of temperature and salinity, and to collect seawater. At each station, water was collected in the morning at 5, 10, 20, 40, 60, 80, 100 and $150 \mathrm{~m}$ during 2006 and at 5, 20, 40,60, 80, 100 and $140 \mathrm{~m}$ in 2007. Some additional depths ( 30 and $50 \mathrm{~m}$ ) were also sampled for parameters at some stations. All samples were processed onboard immediately after sampling.

\subsection{Chemical analysis}

The concentration of chlorophyll- $a(\mathrm{Chl}-a)$ was determined from $250 \mathrm{ml}$ seawater filtered onto glass fibre filters (Whatman $\mathrm{GF} / \mathrm{F}$ ) under low vacuum ( $<200 \mathrm{mbar}$ ), and stored at $-20{ }^{\circ} \mathrm{C}$ before analysis. Pigment extraction was realised in $10 \mathrm{ml}$ of $90 \%$ acetone. Filters were kept overnight in the dark at $-20{ }^{\circ} \mathrm{C}$ and were centrifuged for $10 \mathrm{~min}$ at $5000 \mathrm{rpm}$ at $4{ }^{\circ} \mathrm{C}$ prior to measurement. Chl- $a$ concentration was determined fluorimetrically (Shimadzu RF-1501 spectrofluorophotometer), together with total phaeophytin concentration after acidification $(\mathrm{HCl}, 0.1 \mathrm{~N})$, according to Yentsch and Menzel (1963).

Samples for dissolved organic carbon (DOC) were collected in precombusted glass ampoules $\left(4 \mathrm{~h}, 500{ }^{\circ} \mathrm{C}\right)$ after filtration through GF/F filters also precombusted at $500{ }^{\circ} \mathrm{C}$ for $4 \mathrm{~h}$. Samples $(20 \mathrm{ml})$ were acidified with $100 \mathrm{ml}$ of $85 \%$ phosphoric acid and stored at $4{ }^{\circ} \mathrm{C}$ in the dark until analysis. Samples were analysed using the high-temperature combustion method (TOC-VCSH, 
a
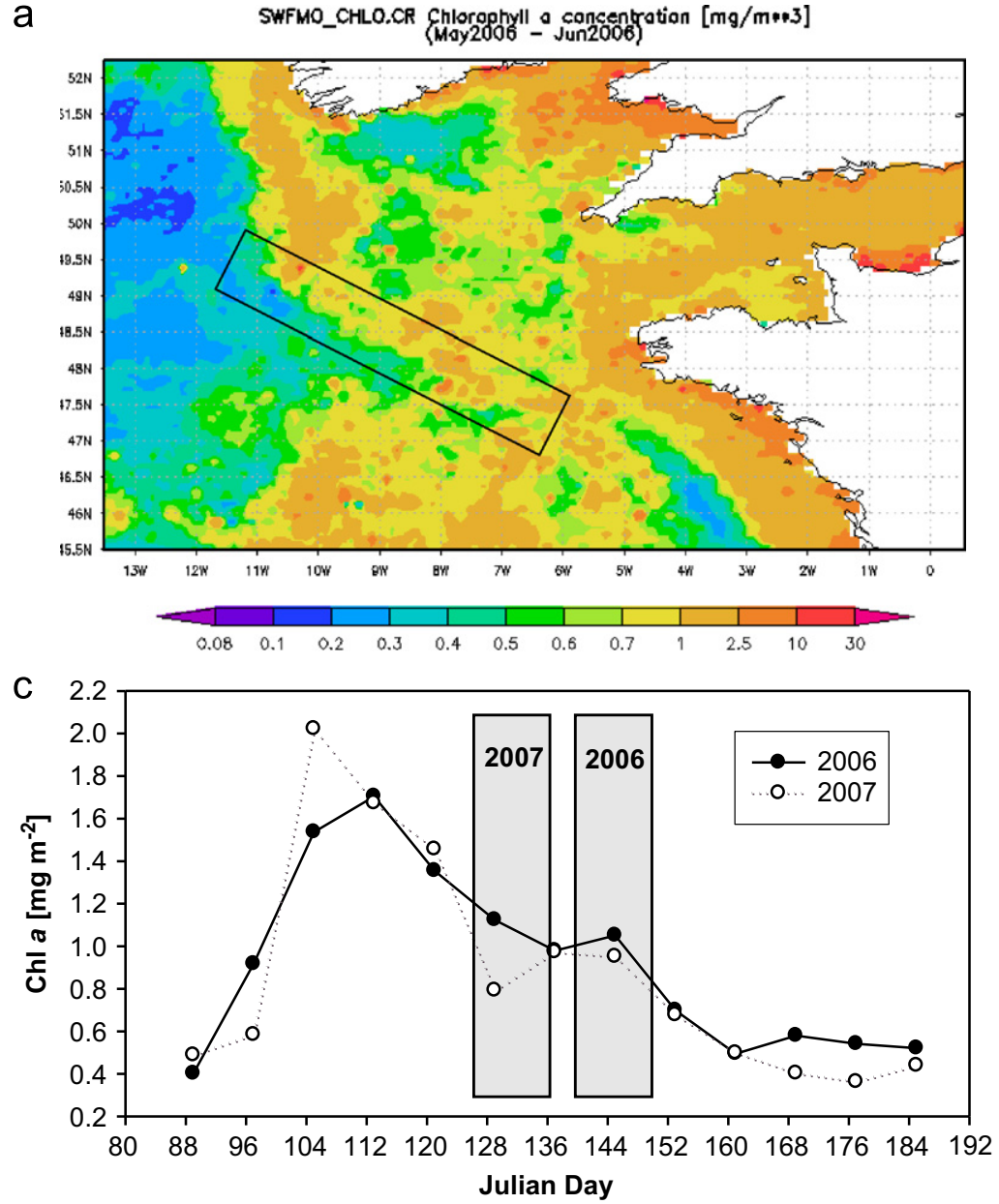

b

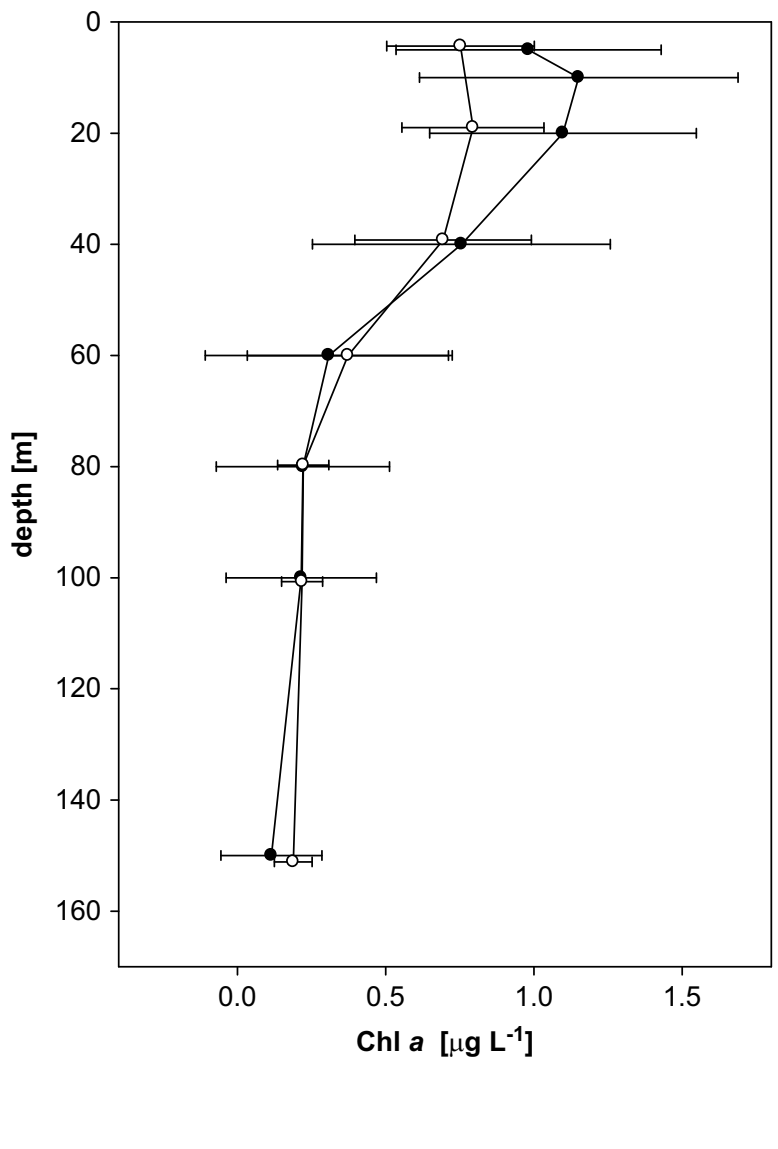

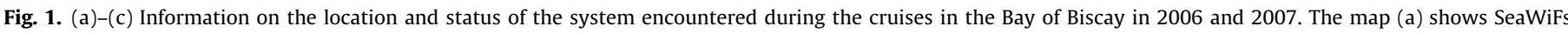

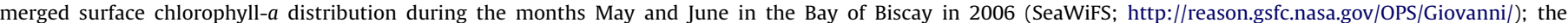

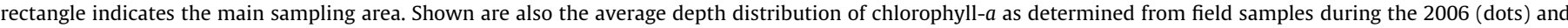

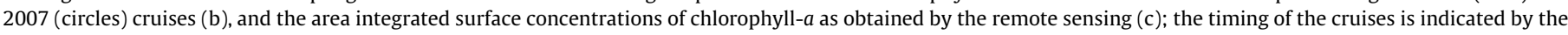
shaded areas.

Shimadzu) (Quian and Mopper, 1996). A multi-point calibration curve was constituted for each day of measurement using potassium hydrogen phthalate standard, which was prepared with MilliQ water. Additionally, two reference seawater standards (Hansell laboratory, RSMAS, University of Miami) were used to determine the instrument blank.

For particulate organic carbon (POC), seawater (200-2000 ml) was filtered onto precombusted $\left(4 \mathrm{~h}, 500^{\circ} \mathrm{C}\right) \mathrm{GF} / \mathrm{F}$ filters using low vacuum ( $<200$ mbar) filtration. The filters containing POC were stored at $-20{ }^{\circ} \mathrm{C}$ until analysis. Within three months after the cruise, the filters were dried overnight at $50{ }^{\circ} \mathrm{C}$ prior to analysis. POC was determined using a Fisons NA-1500 elemental analyser after carbonate removal from the filters by $\mathrm{HCl}$ fumes overnight. Four to five standards of certified reference stream sediment (STSD-2) from the Geological Survey of Canada, together with 3-4 blank filters were used for the calibration. The concentration of total organic carbon (TOC) was calculated as the sum of POC and DOC concentrations.

Transparent exopolymer particles (TEP) were determined after Engel (2009). Briefly, samples were filtered ( $<200$ mbar) onto $0.4 \mu \mathrm{m}$ Nuclepore filters $(25 \mathrm{~mm})$ and stained with $1 \mathrm{ml}$ Alcian Blue. Semi-permanent TEP slides (CytoClear) were prepared by filtration of 5-200 $\mathrm{ml}$ of seawater within $1 \mathrm{~h}$ after sampling. All TEP filters were prepared in duplicates and stored frozen at $-20{ }^{\circ} \mathrm{C}$ until analysis. Microscopic examination of TEP slides was done using a compound light microscope and a digital AxioCam HRc camera (Zeiss) with a 200-400 magnification. About 30 pictures per filter were randomly taken in a cross section. TEP of area size $>1 \mu \mathrm{m}^{2}$ were enumerated and sized for individual area and major cross section. The equivalent spherical diameter (ESD) was calculated for individual particles from area measurements, leading to a range of 1-80 $\mu \mathrm{m}$ (ESD).

TEP were classified according to their ESD into 20 logarithmic size classes (Mari and Burd, 1998). TEP-C was determined from TEP size spectra according to Mari (1999):

$T E P-C=\frac{a}{12} \sum_{i} n_{i} r_{i}^{D}$

The constant, $a=0.25 \times 10^{-6} \mu \mathrm{g} \mathrm{C}$, was determined by Mari (1999). The $n_{i}$ is the concentration of TEP in the size class $i$, and $r_{i}$ is the mean equivalent spherical radius of this size class. The exponent $D$ was determined empirically from the spectral slope, $\delta$, according to the semi-empirical relationship (Burd and Jackson, unpublished data, as referred in Mari and Burd, 1998):

$D=(64-\delta) / 26.2$

More information on the distribution of TEP during the 2006 cruise is given in Harlay et al. (2009).

Carbohydrate monomers released from components $>1 \mathrm{kDa}$ after acid hydrolysis were determined by ion chromatography on 
a Dionex ICS 3000 system using high performance anion exchange chromatography (HPAEC) coupled with pulsed amperometric detection (PAD) after Engel and Händel (2011). High-molecularweight ( $>1 \mathrm{kDa}$ ) dissolved combined carbohydrates (HMWdCCHO) were determined from two replicate samples, filtered through $0.45 \mu \mathrm{m}$ syringe filters (GHP membrane, Acrodisk, Pall) into precombusted glass vials using $20 \mathrm{ml}$ disposable syringes. Particulate carbohydrates ( $\mathrm{pCCHO}$ ) were determined from unfiltered duplicates of $20 \mathrm{ml}$ seawater after subtraction of HMW$\mathrm{dCCHO}$. Low-molecular-weight ( $<1 \mathrm{kDa})$-dCCHO and free sugar monomers were not determined. All samples were immediately frozen and stored at $-20^{\circ} \mathrm{C}$. Prior to filtration, all syringes and syringe filters were rinsed with several $\mathrm{ml}$ of Milli-Q water first and seawater sample thereafter. The samples were thawed immediately before analytical processing. Prior to analysis, desalination of the samples was conducted by membrane dialysis ( $1 \mathrm{kDa}$ MWCO, Spectra Por) for $6 \mathrm{~h}$ at $0^{\circ} \mathrm{C}$. Monomeric carbohydrates were yielded after acid hydrolysis of desalinated samples using $0.8 \mathrm{M} \mathrm{HCl}$ final concentration for $20 \mathrm{~h}$ at $100{ }^{\circ} \mathrm{C}$, and neutralisation through acid evaporation $\left(\mathrm{N}_{2}\right)$. Separation of carbohydrates during chromatography was achieved using a Dionex CarboPac PA10 analytical column $(2 \times 250 \mathrm{~mm})$ coupled with a Dionex CarboPac PA10 guard column $(2 \times 50 \mathrm{~mm})$. Column temperature was kept constant at $17{ }^{\circ} \mathrm{C}$ during all analyses. To minimise degradation of samples before analysis, the autosampler (Dionex AS50) was kept at $4{ }^{\circ} \mathrm{C}$. Carbohydrate analysis was performed by injection of $17.5 \mu \mathrm{l}$ of sample, whereas standardisation was carried out by injection of $10,12.5,15.0$ and $17.5 \mu \mathrm{l}$ of mixed sugar standard solution. In this study we detected the neutral sugars (NS): fucose (Fuc), rhamnose (Rha), arabinose (Ara), galactose (Gal), glucose (Glc), mannose (Man) and xylose (Xyl). Due to co-elution, Man and Xyl were quantified together. Overlapping peaks of Xyl and Man have frequently been reported (Borch and Kirchman, 1997; Kirchman et al., 2001; Goldberg et al., 2009). According to Skoog and Benner (1997) the yield of Man and Xyl in seawater samples is about equal.

We also determined the amino sugar (AS) glucosamine (GlcN), and the acidic sugars (uronic acids, URA): galacturonic acid (GalURA), and glucuronic acid (Glc-URA). All samples were analysed in duplicates, whereas the standard solutions for calibration were measured in triplicates. Milli-Q water was used as blank to account for potential contamination during sample handling. Blanks were treated and analysed in the same way as the samples and subtracted from sample concentration. Recovery of CCHO was checked by analysing the standard solution after every second sample. The detection limit for this method was $10 \mathrm{nmol} \mathrm{L}^{-1}$ with a standard deviation between replicate runs of $<2 \%$, indicating high precision. Concentrations of pCCHO and of HMW-dCCHO after hydrolysis are given as monomer equivalents. In some of the unfiltered samples collected at $>60 \mathrm{~m}$ depth in 2006, values obtained for carbohydrates after subtraction of HMW-dCCHO were zero or slightly below zero, indicating non-detectable amounts of pCCHO. Data for pCCHO from these depths were therefore excluded from further analysis.

\subsection{Data analysis}

For comparison of the amount of carbon contained in different fractions of organic matter encountered during 2006 and 2007, mean values were calculated for each water depth and each year. For describing the changes in CCHO composition over depth, anomalies $\left(A_{x}\right)$ of the molar percentages (\%Mol) of individual carbohydrates were calculated by subtracting the overall mean (Avg.X) of all observations (\%Mol) including all depths from 2006 and 2007 from each single observation $\left(X_{i}\right.$, \% Mol) according to:

$A_{\left(x_{i}\right)}=X_{i}-\operatorname{Avg} . X$

Changes in $A_{x}$ over depth were tested by linear regression. To identify distribution differences of sugar anomalies within the water column, values for $A_{x}$ within the mixed layer ( $<60 \mathrm{~m}$ ) were tested against values for $A_{x}$ below the thermocline ( $>60 \mathrm{~m}$ ) by means of a Mann-Whitney Rank Sum Tests, and were accepted as significant for $p<0.05$. Calculations, statistical tests and illustration of the data were performed with the software packages Microsoft Office Excel and Sigma Plot 12.0 (Systat).

\section{Results}

\subsection{Field situation}

In both years a strong stratification of the water column was observed, with a fully mixed layer within the upper $20 \mathrm{~m}$, a spring-summer thermocline located between 20 and $60 \mathrm{~m}$, and a more homogenous deeper layer (60-160 m) (Fig. 2). Higher surface temperatures were met in 2006, supporting a stronger stratification of surface waters compared to the situation in 2007.

The cruises were carried out after the main spring bloom that in both years peaked in the Bay of Biscay in mid-April, as indicated by composite satellite data (Fig. 1). In 2006, Chl-a concentrations between 0.39 and $1.76 \mu \mathrm{g} \mathrm{L}^{-1}$ (avg. $1.0 \mu \mathrm{g} \mathrm{L}^{-1}$ ) were observed in surface waters $(0-60 \mathrm{~m})$, slightly higher than in 2007, when concentration of Chl- $a$ varied between 0.39 and $1.52 \mu \mathrm{g} \mathrm{L}^{-1}$ (avg. $0.7 \mu \mathrm{g} \mathrm{L}^{-1}$ ). The average depth-profile showed similar Chl- $a$ concentrations below the thermocline $(>60 \mathrm{~m}$ ) for both years, and a more pronounced surface peak in 2006. Phytoplankton community composition in 2006 was dominated by coccolithophores, followed by diatoms, dinoflagellates and prasinophytes, whereas diatoms were the most abundant group - in terms of biomass - during the earlier-in-season cruise of 2007 (Van Oostende, et al., forthcoming). Taken together, the cruise in May 2007 likely encountered a decaying post-bloom diatom system, whereas in June 2006 the cruise coincided with a second bloom, dominated by coccolithophores.

\subsection{Carbon partitioning}

In 2006, station averaged TOC concentrations ranged between 73 and $118 \mu \mathrm{mol} \mathrm{L}^{-1}$ (full range: $57-152 \mu \mathrm{mol} \mathrm{L}^{-1}$ ) and generally decreased with depth. In 2007, TOC concentrations were generally higher than in 2006 and more uniformly distributed over depth, ranging on average between 80 and $112 \mu \mathrm{mol} \mathrm{L}^{-1}$ (full range: $54-121 \mu \mathrm{mol} \mathrm{L}^{-1}$ ) with minimum concentration at $60 \mathrm{~m}$ depth (Fig. 3a, b). Partitioning of TOC into POC and DOC differed between the two years, particularly at depths above $60 \mathrm{~m}$. This was due to both, higher POC concentration and lower DOC concentration in 2006 compared to 2007 (Fig. 3c, d, h). In 2006, station averaged concentrations of POC ranged between 5 and $33 \mu \mathrm{mol} \mathrm{L}^{-1}$, while in 2007 average concentrations between 3 and $14 \mu \mathrm{mol} \mathrm{L}^{-1}$ were observed (Table 1 ). POC contributed between $7 \%$ and $28 \%$ to TOC in 2006, and between $4 \%$ and $14 \%$ in 2007 (Fig. 3a, b). POC concentrations decreased with depth during both years, indicating that organic matter decomposition was efficient in the water column. At greater depth, i.e. 60-140 m, the contribution of POC to TOC was more similar between both years yielding $7-11 \%$ in 2006 and $4-5 \%$ in 2007.

The higher POC concentrations in 2006 were likely due to higher phytoplankton abundance, as indicated by higher Chl- $a$ concentrations (Fig. 1b). Besides plankton organisms, TEP are another identified group of particles that contribute to POC 

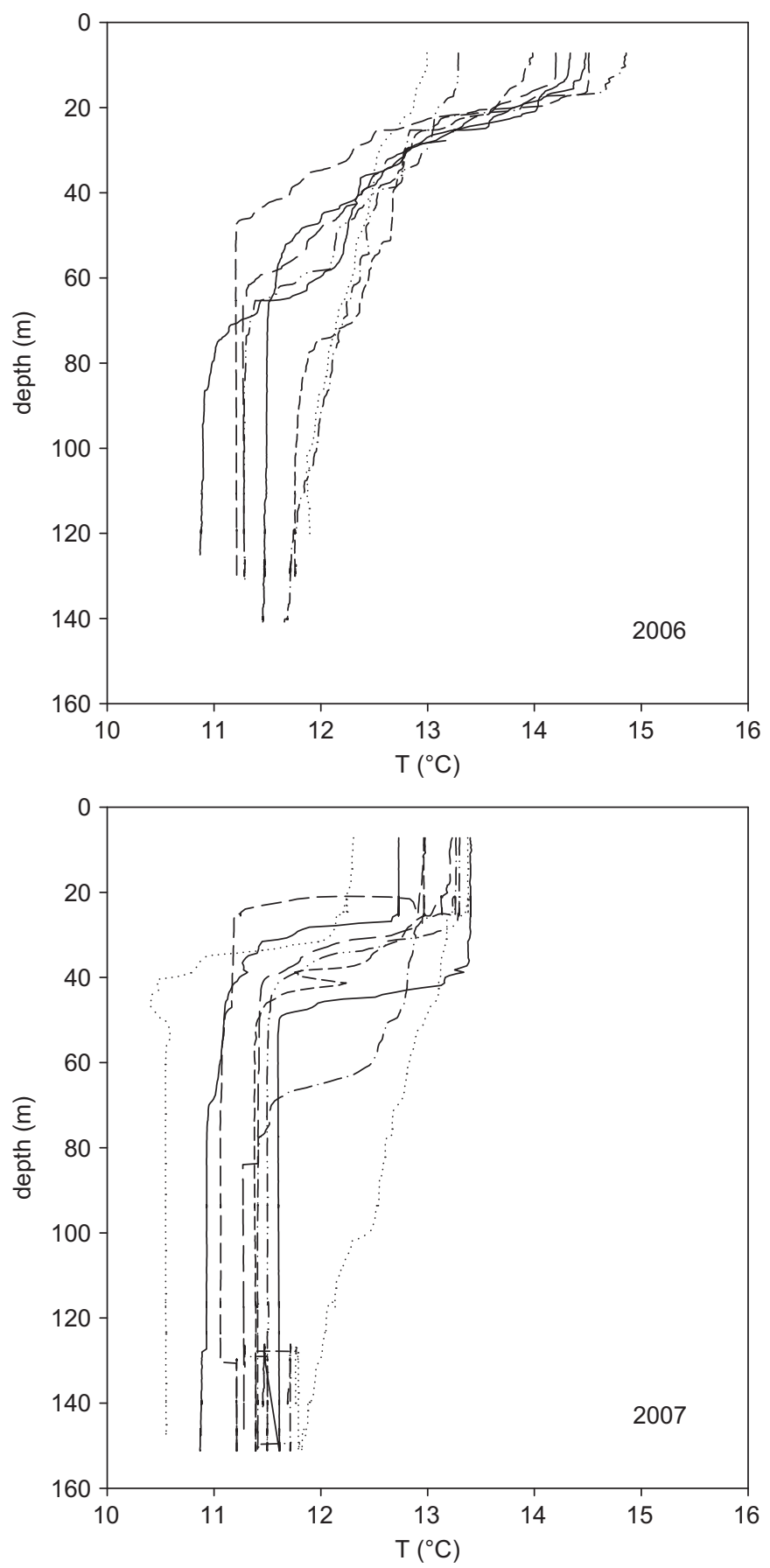

Fig. 2. Depth profile of water temperature $\left({ }^{\circ} \mathrm{C}\right)$ as determined for each station during the cruises in $2006(n=65)$ and $2007(n=61)$.

concentrations (Mari, 1999; Engel and Passow, 2001). In 2006, TEP ( $>1 \mu \mathrm{m}$ ESD) accounted for 0.5 to $1.5 \mu \mathrm{mol} \mathrm{C} \mathrm{L}^{-1}$ on average, and ranged from 0.4 to $2.0 \mu \mathrm{mol} \mathrm{C} \mathrm{L}{ }^{-1}$ in 2007 (Table 1). Surface concentrations of TEP-C were markedly different between the years, yielding 23-74\% higher TEP-C concentrations in 2007 (Table 1). Below the mixed layer, TEP concentrations were quite similar in both years, suggesting a background concentration of $0.5 \mu \mathrm{mol} \mathrm{C} \mathrm{L}{ }^{-1}$. Above $60 \mathrm{~m}$, contribution of TEP-C to POC was relatively low in 2006 with $4.8 \pm 1.4 \%$ compared to $15.4 \pm 3.0 \%$ in 2007 (Fig. 3c, d).

Combined carbohydrates are primarily produced by marine phytoplankton and considered as semi-labile carbon source for heterotrophic organisms. Total concentration of identified combined a

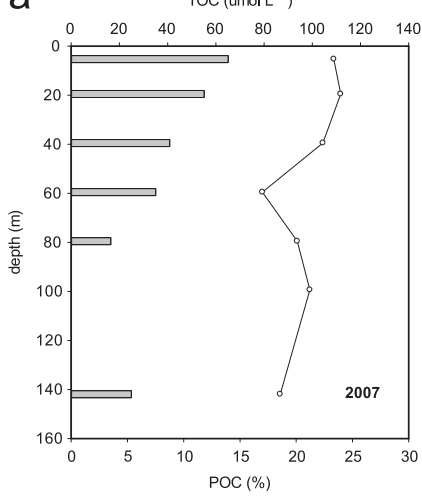

C

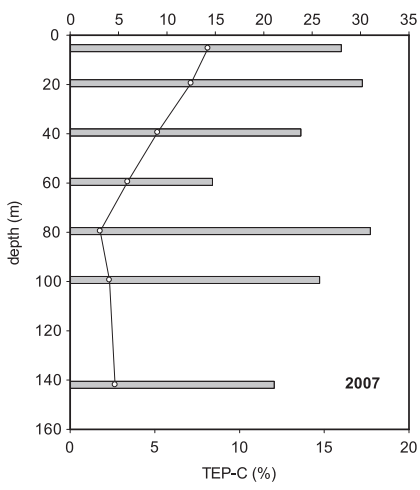

e
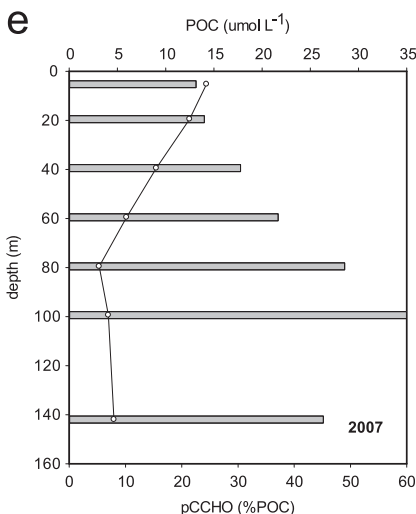

g

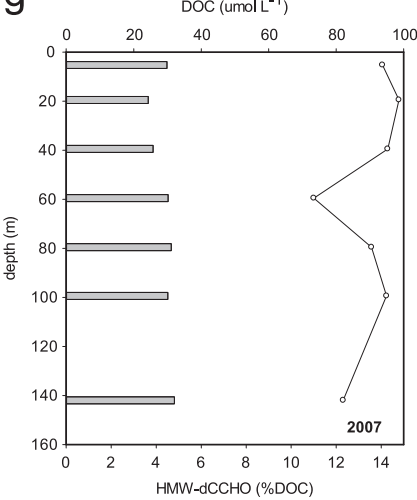

b $\quad$ TOC (umol L-1 $)$

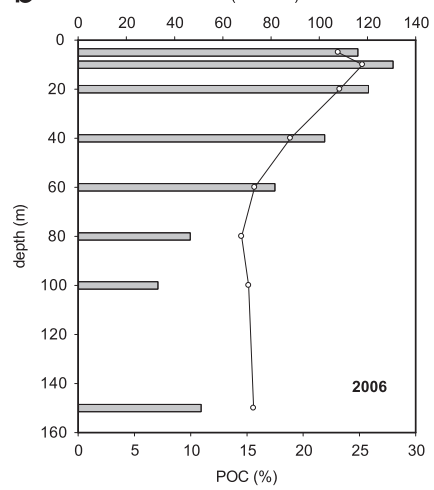

d

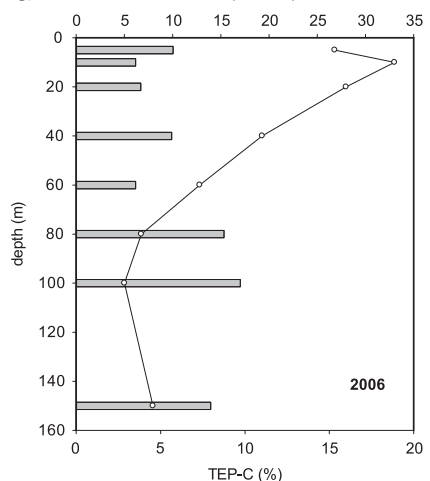

f
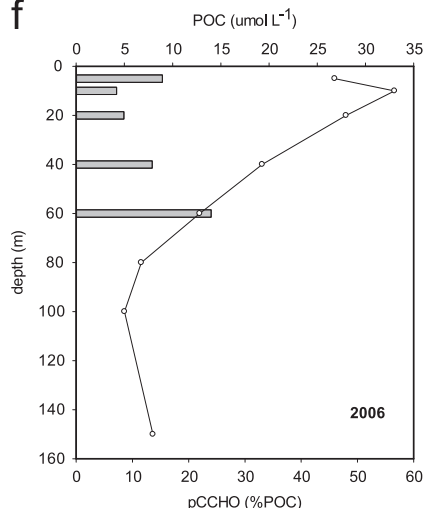

h

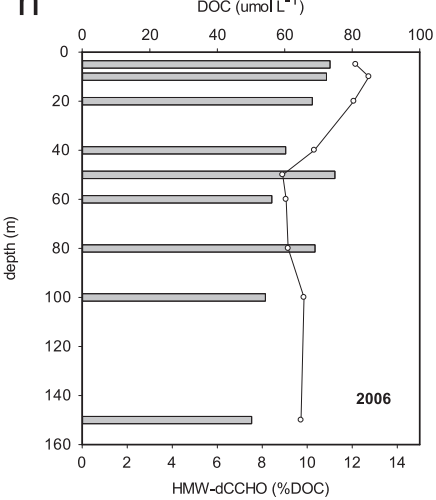

Fig. 3. (a)-(h) Partitioning of organic carbon into different fractions as determined at different depths in 2006 and 2007. Results of the earlier-in-season cruise 2007 are placed to the left. Absolute concentrations are given by symbols and lines, percentages are shown as bars. (a-b) Concentration of TOC and the percentage of TOC contained in POC, (c-d) concentration of POC and the percentage of POC contained in TEP, (e-f) concentration of $\mathrm{POC}$ and the percentage of $\mathrm{POC}$ contained in particulate carbohydrates (pCCHO), (g-h) concentration of DOC and the percentage of DOC contained in high molecular weight dissolved combined carbohydrates (HMW-dCCHO). 
Table 1

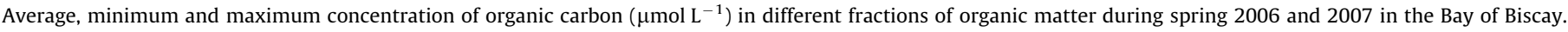

\begin{tabular}{|c|c|c|c|c|c|c|c|c|c|c|c|c|c|c|c|}
\hline \multirow[t]{2}{*}{ Depth (m) } & \multicolumn{3}{|c|}{ POC $(n=95)$} & \multicolumn{3}{|c|}{ DOC $(n=58)$} & \multicolumn{3}{|c|}{ TEP $(n=100)$} & \multicolumn{3}{|c|}{ pCCHO $(n=114)$} & \multicolumn{3}{|c|}{ HMW-dCCHO $(n=114)$} \\
\hline & Avg & Min & Max & Avg & Min & Max & Avg & Min & Max & Avg & Min & Max & Avg & Min & Max \\
\hline \multicolumn{16}{|l|}{2006} \\
\hline 5 & 27 & 18 & 36 & 81 & 71 & 99 & 1.5 & 0.6 & 5.3 & 4.1 & 2.2 & 9.0 & 8.9 & 6.4 & 11.1 \\
\hline 10 & 33 & 25 & 42 & 85 & 69 & 127 & 1.2 & 0.6 & 2.1 & 2.4 & 1.1 & 4.2 & 9.2 & 6.2 & 13.2 \\
\hline 20 & 28 & 23 & 36 & 81 & 66 & 94 & 1.1 & 0.3 & 2.0 & 2.0 & 1.3 & 5.4 & 8.2 & 5.9 & 11.3 \\
\hline 30 & - & - & - & - & - & - & 0.9 & 0.2 & 1.6 & 2.0 & 0.7 & 4.5 & 7.2 & 4.5 & 10.3 \\
\hline 40 & 19 & 19 & 20 & 69 & 62 & 88 & 1.1 & 0.2 & 2.0 & 2.6 & 1.2 & 3.9 & 6.2 & 4.4 & 7.1 \\
\hline 50 & - & - & - & 59 & 48 & 701 & 0.8 & 0.6 & 1.1 & 3.0 & 0.3 & 5.7 & 6.7 & 3.9 & 9.4 \\
\hline 60 & 13 & 5.1 & 26 & 60 & 49 & 77 & 0.5 & 0.1 & 1.0 & 3.1 & 1.2 & 5.5 & 5.1 & 4.1 & 6.3 \\
\hline 80 & 6.8 & 4.1 & 8.8 & 61 & 50 & 70 & 0.6 & 0.2 & 1.1 & - & - & - & 6.3 & 4.7 & 7.9 \\
\hline 100 & 5.0 & 4.1 & 5.7 & 66 & 61 & 70 & 0.5 & 0.0 & 1.0 & - & - & - & 5.4 & 4.4 & 6.3 \\
\hline 150 & 8.0 & 3.2 & 19 & 65 & 57 & 71 & 0.6 & 0.2 & 1.0 & - & - & - & 4.9 & 4.2 & 6.2 \\
\hline \multicolumn{16}{|l|}{2007} \\
\hline 5 & 14 & 6.1 & 20 & 94 & 80 & 102 & 1.9 & 0.2 & 5.8 & 3.3 & 0.9 & 7.3 & 4.2 & 1.4 & 5.9 \\
\hline 20 & 13 & 6.2 & 17 & 99 & 92 & 105 & 2.0 & 0.2 & 7.0 & 2.6 & 0.7 & 4.8 & 3.6 & 0.8 & 6.8 \\
\hline 40 & 9.0 & 5.2 & 11 & 95 & 84 & 114 & 1.7 & 0.1 & 5.9 & 2.9 & 1.3 & 6.1 & 3.7 & 1.1 & 6.4 \\
\hline 60 & 5.9 & 2.3 & 10 & 73 & 46 & 94 & 0.4 & 0.1 & 0.9 & 1.5 & 0.7 & 2.0 & 3.3 & 0.7 & 6.1 \\
\hline 80 & 3.1 & 1.8 & 4.7 & 90 & 80 & 105 & 0.5 & 0.2 & 1.1 & 1.6 & 0.6 & 2.7 & 4.2 & 0.7 & 9.8 \\
\hline 100 & 4.1 & 1.6 & 5.6 & 95 & 75 & 109 & 0.5 & 0.3 & 1.0 & 2.3 & 1.0 & 3.9 & 4.3 & 2.9 & 5.8 \\
\hline 140 & 4.6 & 2.9 & 7.4 & 82 & 61 & 10 & 0.5 & 0.2 & 0.8 & 4.1 & 1.2 & 9.6 & 3.9 & 0.6 & 6.2 \\
\hline
\end{tabular}

carbohydrates $(\mathrm{CCHO}=\mathrm{pCCHO}+\mathrm{HMW}-\mathrm{dCCHO})$ decreased with depth in both years. Thereby, higher surface concentrations and a steeper decrease were observed in 2006, for pCCHO and HMWdCCHO as well (Table 1). On average, CCHO contributed between $8 \%$ and $12 \%$ to TOC in 2006, and less in 2007 with values between $6 \%$ and 9\% (data not shown). Particulate CCHO (pCCHO) concentration was $<4.1 \mu \mathrm{mol} \mathrm{C} \mathrm{L}{ }^{-1}$, and rather similar between the two years, showing only slightly higher values towards the surface in 2006 (Table 1). However, due to the lower POC concentrations measured in 2007, the contribution of pCCHO to POC was much higher in 2007, where station-averaged values ranged between $22 \%$ and $60 \%$, compared to 2006 with values comprising between $3 \%$ and $10 \%$ (Table 1, Fig. 3e,f).

In contrast, concentration of HMW-dCCHO was twice as high in 2006 compared to 2007 (Table 1). Because of the lower DOC concentration, relative contribution of HMW-dCCHO to DOC was even more pronounced in 2006, yielding an average of $9.2 \pm 1.5 \%$ (range: 5-13\%), compared to 2007 with an average percentage of $4.1 \pm 2.3 \%$ (range: $0.9-10.2 \%$ ) (Fig. $3 g, h$ ). Hence, combined carbohydrates contributed to a larger fraction of POC in 2007 and to a larger fraction of DOC in 2006.

In accordance with a higher contribution of pCCHO to POC in 2007 compared to 2006, we observed more TEP during the earlier-in season cruise (2007). In 2006, carbon contained in TEP ( $>1 \mu \mathrm{m}$ ESD) was equivalent to $4-10 \%$ of POC. In 2007, contribution of TEP-C to POC was about twice as high with values ranging between $8 \%$ and $18 \%$ (Fig. 3c,d). TEP are polysaccharide-rich gels that are formed from dissolved precursors. During both years, TEP were identified as a substantial fraction of CCHO. Within the upper $60 \mathrm{~m}$, carbon contained in TEP (TEP-C) was equivalent to about $40 \%$ of pCCHO-C in 2006 , and to about $60 \%$ of pCCHO-C in 2007. Hence, TEP were a substantial component of pCCHO that can partly explain the carbohydrate enrichment of POC in 2007.

The ratio of pCCHO:POC increased with depth in both years, indicating that particles became enriched in pCCHO during their descent to depth, either by selectively binding to carbon-rich substances, or by preferential removal of non-carbohydrate components. The relative increase in pCCHO over depth clearly differed from the depth profile of Chl- $a$ concentration that exhibited higher values towards the sunlit surface ocean (Fig. 1b).

\subsection{Combined carbohydrate (CCHO) determination}

\subsubsection{CCHO composition and carbon yield of sugars}

Three types of sugar monomers, released from combined carbohydrates after acid hydrolysis, were determined during this study: neutral sugars (NS) - including also the deoxy-sugars Fuc and Rha-, the amino sugar (AS) GlcN, and the uronic acids (URA) Glc-URA and Gal-URA.

Concentration of NS in CCHO decreased with depth in the particulate as well as in the HMW-DOM fraction (Table 2). In 2006, highest station averaged concentrations of $532 \mathrm{nmol} \mathrm{L}^{-1}$ (pCCHO) and $1113 \mathrm{nmol} \mathrm{L}^{-1}$ (HMW-dCCHO) were observed at the shallowest depth, decreasing to $239 \mathrm{nmol} \mathrm{L}^{-1}$ (pCCHO at $60 \mathrm{~m}$ ) and $552 \mathrm{nmol} \mathrm{L}^{-1}$ (HMW-dCCHO at $150 \mathrm{~m}$ ), respectively (Table 2). In 2007, station averaged surface $(5 \mathrm{~m})$ concentration of NS were similar for pCCHO with $515 \mathrm{nmol} \mathrm{L}^{-1}$ but clearly lower for HMW-dCCHO with $591 \mathrm{nmol} \mathrm{L}^{-1}$, and the decrease of NS over depth was not as pronounced as in 2006. Carbon yield (\%OC) of total NS during both years ranged between $8 \%$ at the surface and 3-7\% below the mixed layer. URA were the second most abundant group of sugars in both years. Station averaged concentration of URA in HMW-dCCHO declined with depth, although not as pronounced as observed for NS (Table 2). In contrast, concentration of URA in pCCHO increased with depth, particularly during 2007. Moreover, HMW-dURA concentration below the thermocline was rather similar during both years, whereas pURA was clearly higher at depth in 2006. From the group of AS, only GlcN was detectable. Station averaged concentrations of GlcN were higher in 2006 than in 2007, and higher for HMWdAS than for pAS (Table 2). Like for HMW-dURA, decrease of HMWdGlcN concentration with depth was not as pronounced as for HMWdNS. Concentrations of pAS increased with depth. Carbon yield of GlcN in the particulate and in the HMW phases was $<1 \% \mathrm{OC}$ during both years.

\subsubsection{Molar composition analysis of $\mathrm{CCHO}$}

Distribution of sugars within the water column is determined by the balance between production and decomposition processes, as well as by physical transport processes such as mixing and particle sinking. In general, we assumed net production of neutral sugars in the euphotic zone, primarily due to primary production, 
Table 2

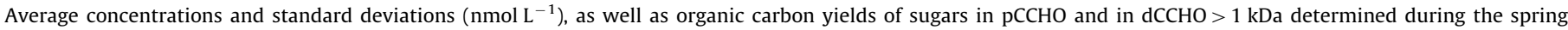
seasons in the Bay of Biscay in 2006 and 2007.

\begin{tabular}{|c|c|c|c|c|c|c|c|c|c|c|c|c|}
\hline \multirow{3}{*}{$\begin{array}{l}\text { Depth } \\
\text { (m) }\end{array}$} & \multicolumn{6}{|c|}{$H M W-d C C H O$} & \multicolumn{6}{|c|}{ pCCHO } \\
\hline & NS & NS & URA & URA & AS & AS & NS & NS & URA & URA & AS & AS \\
\hline & $\mathrm{nM}$ & $\% \mathrm{DOC}$ & $\mathrm{nM}$ & $\% \mathrm{DOC}$ & $\mathrm{nM}$ & $\% \mathrm{DOC}$ & $\mathrm{nM}$ & $\%$ POC & $\mathrm{nM}$ & $\% \mathrm{POC}$ & $\mathrm{nM}$ & $\% \mathrm{POC}$ \\
\hline \multicolumn{13}{|l|}{2006} \\
\hline 5 & 1113 & 8.2 & 316 & 2.3 & 27 & 0.2 & 532 & 11.9 & 132 & 3.0 & 20 & 0.5 \\
\hline 10 & 1135 & 8.0 & 345 & 2.4 & 24 & 0.2 & 317 & 5.8 & 65 & 1.2 & 12 & 0.2 \\
\hline 20 & 979 & 7.3 & 320 & 2.4 & 22 & 0.2 & 250 & 6.0 & 84 & 2.0 & 18 & 0.4 \\
\hline 30 & 796 & - & 336 & - & 21 & - & 261 & & 71 & & 4 & \\
\hline 40 & 679 & 5.9 & 314 & 2.7 & 15 & 0.1 & 307 & 9.5 & 121 & 3.8 & 8 & 0.2 \\
\hline 50 & 762 & 7.7 & 298 & 3.0 & 15 & 0.2 & 342 & & 152 & & 3 & \\
\hline 60 & 638 & 6.3 & 194 & 1.9 & 13 & 0.1 & 239 & 11.2 & 271 & 12.7 & 2 & 0.1 \\
\hline 80 & 753 & 7.4 & 289 & 2.8 & 13 & 0.1 & - & - & - & - & - & - \\
\hline 100 & 650 & 5.9 & 232 & 2.1 & 10 & 0.1 & - & - & - & - & - & - \\
\hline 150 & 552 & 5.1 & 249 & 2.3 & 12 & 0.1 & - & - & - & - & - & - \\
\hline \multicolumn{13}{|l|}{2007} \\
\hline 5 & 591 & 3.8 & 109 & 0.7 & 19.1 & 0.1 & 515 & 21 & 32 & 1 & 4 & 0.2 \\
\hline 20 & 456 & 2.8 & 143 & 0.9 & 13.8 & 0.1 & 409 & 23 & 20 & 1 & 5 & 0.2 \\
\hline 40 & 460 & 2.9 & 153 & 1.0 & 17.3 & 0.1 & 447 & 27 & 43 & 3 & 1 & 0.1 \\
\hline 60 & 398 & 3.3 & 156 & 1.3 & 12.7 & 0.1 & 208 & 33 & 49 & 4 & 1 & 0.1 \\
\hline 80 & 549 & 3.6 & 155 & 1.0 & 7.4 & 0.0 & 251 & 45 & 20 & 3 & 3 & 0.6 \\
\hline 100 & 482 & 3.0 & 233 & 1.5 & 6.1 & 0.0 & 315 & 45 & 93 & 14 & 5 & 0.7 \\
\hline 140 & 521 & 3.8 & 136 & 1.0 & 11.8 & 0.1 & 376 & 37 & 104 & 8 & 2 & 0.2 \\
\hline
\end{tabular}

Table 3

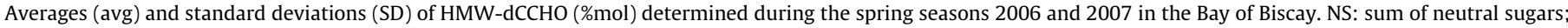
URA: sum of uronic acids; $n=$ number of samples.

\begin{tabular}{|c|c|c|c|c|c|c|c|c|c|c|c|c|c|c|c|c|c|c|c|c|c|c|c|}
\hline \multirow[t]{2}{*}{ Depth (m) } & \multicolumn{2}{|l|}{ Fuc } & \multicolumn{2}{|l|}{ Rha } & \multicolumn{2}{|l|}{ Ara } & \multicolumn{2}{|c|}{ GlcN } & \multicolumn{2}{|l|}{ Gal } & \multicolumn{2}{|l|}{ Glc } & \multicolumn{2}{|c|}{ Man./Xyl. } & \multicolumn{2}{|c|}{ Gal-URA } & \multicolumn{2}{|c|}{ Glc-URA } & \multicolumn{2}{|l|}{ NS } & \multicolumn{2}{|l|}{ URA } & \multirow[t]{2}{*}{$n$} \\
\hline & Avg & SD & Avg & SD & Avg & SD & Avg & SD & Avg & SD & Avg & SD & Avg & SD & Avg & SD & Avg & SD & Avg & SD & Avg & SD & \\
\hline \multicolumn{24}{|l|}{2006} \\
\hline 5 & 5.0 & 2.6 & 6.6 & 6.3 & 2.8 & 0.9 & 1.8 & 0.6 & 9.4 & 2.6 & 39.0 & 13.5 & 12.0 & 2.3 & 13.8 & 12.6 & 13.1 & 6.8 & 74.8 & 7.3 & 21.3 & 10.6 & 7 \\
\hline 10 & 4.7 & 2.9 & 6.6 & 5.7 & 3.0 & 1.2 & 1.6 & 0.5 & 8.9 & 3.1 & 38.1 & 13.9 & 12.5 & 4.6 & 15.9 & 15.2 & 12.3 & 7.2 & 73.9 & 8.5 & 22.4 & 11.9 & 6 \\
\hline 20 & 4.5 & 1.9 & 5.5 & 3.3 & 3.3 & 0.6 & 1.6 & 0.7 & 9.5 & 1.8 & 35.0 & 7.9 & 13.6 & 5.7 & 15.1 & 14.1 & 18.1 & 7.9 & 71.4 & 5.3 & 23.3 & 11.0 & 8 \\
\hline 30 & 3.9 & 2.3 & 4.5 & 3.5 & 3.2 & 1.1 & 1.8 & 0.8 & 7.2 & 2.8 & 34.9 & 14.3 & 12.8 & 5.2 & 19.5 & 19.2 & 15.8 & 9.4 & 66.4 & 10.5 & 28.1 & 15.5 & 7 \\
\hline 40 & 2.7 & 0.9 & 5.0 & 4.7 & 3.4 & 1.9 & 1.5 & 0.5 & 6.3 & 3.2 & 35.1 & 17.8 & 13.1 & 4.6 & 16.1 & 17.4 & 19.3 & 12.2 & 65.5 & 11.2 & 30.3 & 15.5 & 7 \\
\hline 50 & 2.3 & 1.0 & 3.5 & 2.8 & 3.0 & 1.6 & 1.4 & 0.7 & 4.3 & 2.3 & 45.3 & 12.8 & 10.6 & 2.4 & 12.9 & 14.2 & 18.3 & 13.4 & 68.5 & 11.3 & 26.8 & 15.2 & 6 \\
\hline 60 & 2.6 & 0.7 & 4.3 & 3.7 & 4.4 & 3.0 & 1.5 & 0.4 & 6.1 & 3.3 & 46.3 & 20.3 & 13.9 & 4.9 & 14.7 & 12.4 & 14.5 & 10.1 & 75.2 & 12.3 & 22.9 & 12.9 & 7 \\
\hline 80 & 1.6 & 0.5 & 4.4 & 1.8 & 2.7 & 1.6 & 1.2 & 0.5 & 3.7 & 2.2 & 50.4 & 15.4 & 10.2 & 3.9 & 20.9 & 16.0 & 13.5 & 8.8 & 71.5 & 14.3 & 27.5 & 14.2 & 6 \\
\hline 100 & 2.0 & 0.3 & 1.7 & - & 2.1 & 1.3 & 1.1 & 0.0 & 4.1 & 1.4 & 50.8 & 10.3 & 13.3 & 0.8 & 1.1 & 1.1 & 25.7 & 10.0 & 72.9 & 10.6 & 26.0 & 10.6 & 4 \\
\hline 150 & 2.1 & 0.5 & 5.2 & 2.4 & 2.0 & 1.6 & 1.4 & 0.4 & 4.8 & 2.1 & 46.8 & 16.2 & 9.6 & 2.6 & 21.1 & 19.8 & 14.9 & 10.4 & 67.9 & 15.5 & 30.7 & 15.3 & 4 \\
\hline \multicolumn{24}{|l|}{2007} \\
\hline 5 & 4.9 & 2.2 & 6.1 & 4.8 & 3.4 & 2.2 & 2.7 & 1.3 & 10.4 & 7.0 & 44.6 & 10.6 & 12.2 & 5.0 & 0.7 & 2.0 & 14.9 & 14.8 & 84.5 & 14.1 & 15.5 & 14.1 & 9 \\
\hline 20 & 5.0 & 2.1 & 6.3 & 4.2 & 3.7 & 2.4 & 2.3 & 1.8 & 10.7 & 7.9 & 36.0 & 17.4 & 12.1 & 5.2 & 1.9 & 4.6 & 22.0 & 22.3 & 76.1 & 20.6 & 23.9 & 20.6 & 8 \\
\hline 40 & 3.8 & 2.4 & 4.3 & 4.5 & 3.2 & 2.3 & 2.8 & 1.4 & 9.5 & 6.5 & 42.5 & 11.5 & 8.8 & 4.6 & 2.2 & 4.8 & 22.7 & 21.9 & 75.0 & 19.7 & 25.0 & 19.7 & 9 \\
\hline 60 & 2.2 & 1.0 & 1.4 & 2.0 & 3.0 & 1.6 & 2.3 & 1.5 & 5.2 & 3.1 & 46.8 & 15.6 & 10.9 & 4.6 & 3.3 & 8.8 & 24.7 & 23.7 & 71.9 & 21.1 & 28.1 & 21.1 & 8 \\
\hline 80 & 1.5 & 0.9 & 1.4 & 2.3 & 1.7 & 1.5 & 1.0 & 1.1 & 4.2 & 7.0 & 60.5 & 8.3 & 7.7 & 5.5 & 4.2 & 6.5 & 17.8 & 17.3 & 78.0 & 13.2 & 22.0 & 13.2 & 9 \\
\hline 100 & 1.2 & 1.0 & 0.9 & 1.2 & 1.1 & 0.8 & 0.9 & 0.9 & 2.8 & 3.0 & 52.3 & 21.3 & 8.3 & 7.3 & 2.6 & 4.2 & 29.9 & 27.9 & 67.4 & 24.5 & 32.6 & 24.5 & 8 \\
\hline 140 & 1.6 & 1.0 & 1.9 & 2.5 & 2.0 & 1.7 & 1.8 & 2.2 & 2.6 & 3.8 & 59.1 & 13.4 & 10.3 & 6.8 & 3.4 & 5.9 & 17.3 & 19.4 & 79.3 & 16.4 & 20.7 & 16.4 & 5 \\
\hline
\end{tabular}

and net decomposition of neutral sugars in the aphotic, deeper water column.

Among all carbohydrates determined during this study, Glc was the dominant one in all samples during both years. The fraction of Glc ranged between $35 \%$ and $61 \% \mathrm{Mol}$ in HMW-dCCHO (Table 3 ), and between $20 \%$ and $74 \% \mathrm{Mol}$ in pCCHO (Table 4 ). Percentages of NS other than Glc declined in the following order: Man/Xyl $>$ Gal $>$ Rha $>$ Fuc $>$ Ara in pCCHO as well as in HMWdCCHO (Tables 3 and 4). Glc-URA and Gal-URA contributed substantially to pCCHO and HWM-dCCHO during both years. During 2006, Gal-URA was almost as abundant as Glc-URA in HMW-dCCHO (Table 3), and even more abundant in pCCHO (Table 4), yielding maximum values where high abundances of coccolithophores, predominantly Emiliania huxleyi, were observed (Van Oostende et al., forthcoming). Relative abundance (\%Mol) of URA in HMW-dCCHO was significantly negatively correlated to TEP in $2006(p<0.001, n=63)$ and in $2007(p<0.001, n=56)$, suggesting that URA were removed from the HMW-dCCHO fraction during TEP formation. However, no significant relationship between pCCHO composition, specifically URA, and TEP was detected during both years. TEP abundance in 2006 was also strongly correlated to the combined percentages of the neutral deoxy-sugars Fuc and Rha $(p<0.001, n=52)$ in HMW-dCCHO. The amino sugar GlcN, was the least abundant identified carbohydrate and contributed on average $0.9-2.8 \% \mathrm{Mol}$, and $0.4-5.0 \% \mathrm{Mol}$ to $\mathrm{HMW}$-dCCHO and pCCHO, respectively. 


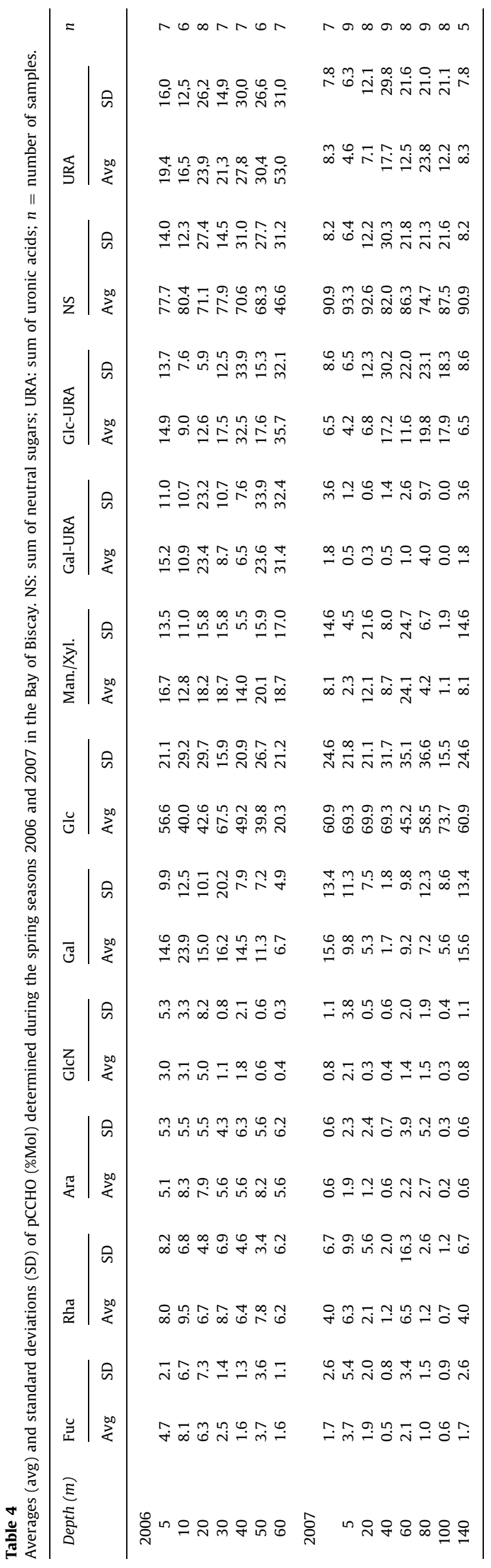

To characterise changes in $\mathrm{CCHO}$ composition with depth, we computed the anomalies of \%Mol $\left(A_{x i}\right)$ of each carbohydrate monomer $\left(x_{i}\right)$ according to Eq. (3); i.e. the difference between the relative abundance of a carbohydrate at a particular depth with respect to the mean value of all observations of that component during 2006 and 2007. For more labile carbohydrates, we expect positive anomalies within the upper mixed layer, and negative anomalies below. Refractory sugars are degraded at a very slow rate and would show a more even distribution in the water column, as the time of decomposition exceeds the time of physical mixing ( $>1$ year). Some sugars like AS and URA are produced by auto- as well as heterotrophic organisms, and thus may have another source deeper in the water column, potentially explaining positive anomalies below the mixed layer. Besides mixing, particle sinking is another process exporting sugars to depth. A larger anomaly of \%Mol of sugars at depth may therefore also indicate sugars seasonally exported by particle sinking with a turn-over time of $<1$ year.

Because the composition of HMW-dCCHO and pCCHO was rather similar, we used the molar composition of carbohydrates determined in the unfiltered sample, i.e. $\mathrm{CCHO}=\mathrm{pCCHO}+\mathrm{HMW}-$ $\mathrm{dCCHO}$, to investigate sources of variance in sugar composition. Since the molar composition of $\mathrm{CCHO}$ varied with water depth, but did not differ significantly between the two years (Kolmogorov-Smirnov test, $p>0.05$ for each sugar), values for $A x$ were calculated for each depth and relative to their overall average in all samples ( $n=119$ ) from the two years (Table 5 ).

For the two field campaigns in 2006 and 2007, highest positive anomalies within the surface mixed layer were determined for Gal, Fuc, Rha and Ara. Average values (median) for $A_{x}$ of these sugars were significantly higher within the surface mixed layer than below $(p<0.01$; Table 5), indicating that the rate of consumption below the thermocline clearly exceeded the rate of supply by physical mixing ( $>1$ year) and by particles sinking ( $>1$ month). For the sugars Man/Xyl, GlcN and Gal-URA, anomalies were more evenly distributed over depth and $A_{x}$-values did not differ significantly between the surface mixed layer and below the thermocline. For Gal-URA, a cluster of positive anomalies was observed in the upper $40 \mathrm{~m}$, representing samples collected during the coccolithophore bloom in 2006 (data not shown). Glc and Glc-URA displayed highest positive anomalies within the deeper water column. The CCHO below the thermocline were significantly enriched in the neutral sugar Glc $(p<0.05$; Table 5), suggesting that Glc is less susceptible to degradation than other NS, or preferentially exported to depth by sinking particles.

The absolute differences in average \%Mol between the water column above the thermocline $(0-60 \mathrm{~m})$, and below $(>60 \mathrm{~m})$ were calculated for the two years separately, and are shown in Fig. 4. In accordance with the anomaly analysis, Gal, Rha and Fuc were relatively more abundant in the upper water column during both years, while Glc, Glc-URA and Gal-URA in 2006 were relatively enriched in the lower water column. Smaller changes over depth were observed for Ara, GlcN and Man/Xyl.

An indication for the diagenetic alteration of CCHO was also inferred from the correlation of individual carbohydrates to concentrations of Chl- $a$, taking Chl-a as an indicator for fresh algal biomass. Among the individual carbohydrates within HMW$\mathrm{dCCHO}$ and $\mathrm{pCCHO}$ that were significantly correlated $(p<0.01)$ to Chl-a, we found Gal, Rha (except 2006), Ara (except for pCCHO in 2006), Fuc, and Man/Xyl in order of decreasing correlation coefficient (Fig. 5). In general, URA were negatively correlated to Chl- $a(p<0.01)$, except for HMW-dGlc-URA in 2006. Interestingly, Glc correlated negatively with Chl- $a$ in HMW-dCCHO, but positively in pCCHO. This is in accordance with the assumption of Glc production by phytoplankton in the sunlit ocean and the release of Glc from sinking particles deeper in the water column. 
Table 5

Statistics of the observed anomalies $\left(A_{x i}\right)$ of total determined carbohydrates $(\mathrm{CCHO}=\mathrm{pCCHO}+\mathrm{HMW}-\mathrm{dCCHO}$; \% $\mathrm{Mol})$ in the Bay of Biscay in spring 2006 and 2007. Differences between the anomalies of individual sugars within and below the mixed layer ( $\sim 60 \mathrm{~m}$ ) were compared by means of Mann-Whitney Rank Sum Tests. URA, uronic acids; NS, neutral sugars; $r$, correlation coefficient.

\begin{tabular}{llllr}
\hline & $\begin{array}{c}A(\text { median }) \\
<60 \mathrm{~m} ;(n=67)\end{array}$ & $\begin{array}{l}A(\text { median }) \\
>60 \mathrm{~m} ;(n=52)\end{array}$ & & $r$ (anomaly; depth) \\
& & & & \\
\hline Fuc & 1.22 & -1.24 & $<0.001$ & -0.50 \\
Rha & -0.12 & -2.23 & $<0.001$ & -0.36 \\
Ara & -0.24 & -1.35 & $<0.001$ & -0.23 \\
GlcN & -0.27 & -0.23 & 0.410 & -0.10 \\
Gal & 1.22 & -3.54 & $<0.001$ & -0.45 \\
Glc & -4.69 & 3.48 & $<0.05$ & 0.21 \\
Man/Xyl & -0.15 & -2.50 & 0.257 & -0.12 \\
Gal-URA & -7.04 & -7.87 & 0.444 & 0.00 \\
Glc-URA & -0.33 & 2.86 & 0.674 & 0.16 \\
URA & -0.90 & 0.51 & 0.358 & 0.15 \\
NS & 0.99 & -1.55 & 0.420 & -0.14 \\
\end{tabular}

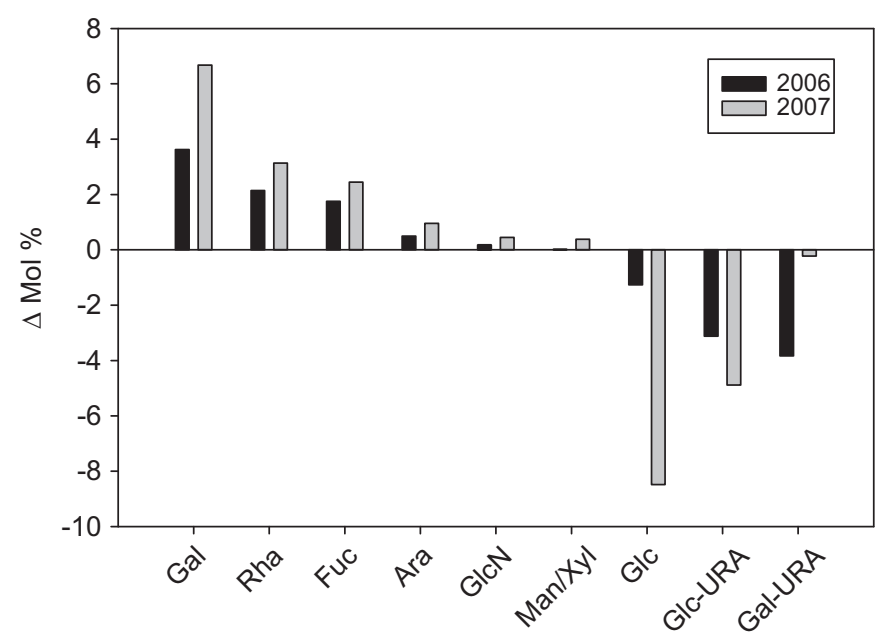

Fig. 4. Differences in the molar percentages of individual sugars contained in CCHO between the upper $60 \mathrm{~m}$ and the lower water column $(60-150 \mathrm{~m})$. For each sugar, $n=58$ in 2006, $n=56$ in 2007.

\section{Discussion}

\subsection{Comparison of the field situations in 2006 and 2007}

Two cruises were conducted after the diatom spring bloom in the Bay of Biscay (2006, 2007), and showed clear differences in terms of organic carbon partitioning between dissolved and particulate forms. Based on satellite information of the field site, we assume that the vernal development in general was similar for both years: a spring bloom system in April, followed by a postbloom phase in May and a second smaller bloom dominated by coccolithophores at the transition to summer. Since the cruise in 2007 was conducted two weeks earlier than the one in 2006, the situation met in 2007 rather mirrored the post-bloom situation, whilst in 2006 the coccolithophore bloom was already observed at several stations. In the northern Bay of Biscay, the occurrence of a second phytoplankton bloom, dominated by coccolithophores (E. huxleyi), is induced by nutrients upwelling at the continental margin (Harlay et al., 2010). Hence, we assume that our results from 2007 characterise the earlier-in-season, post-diatom bloom situation. At this time, Chl- $a$ concentration and POC yield,
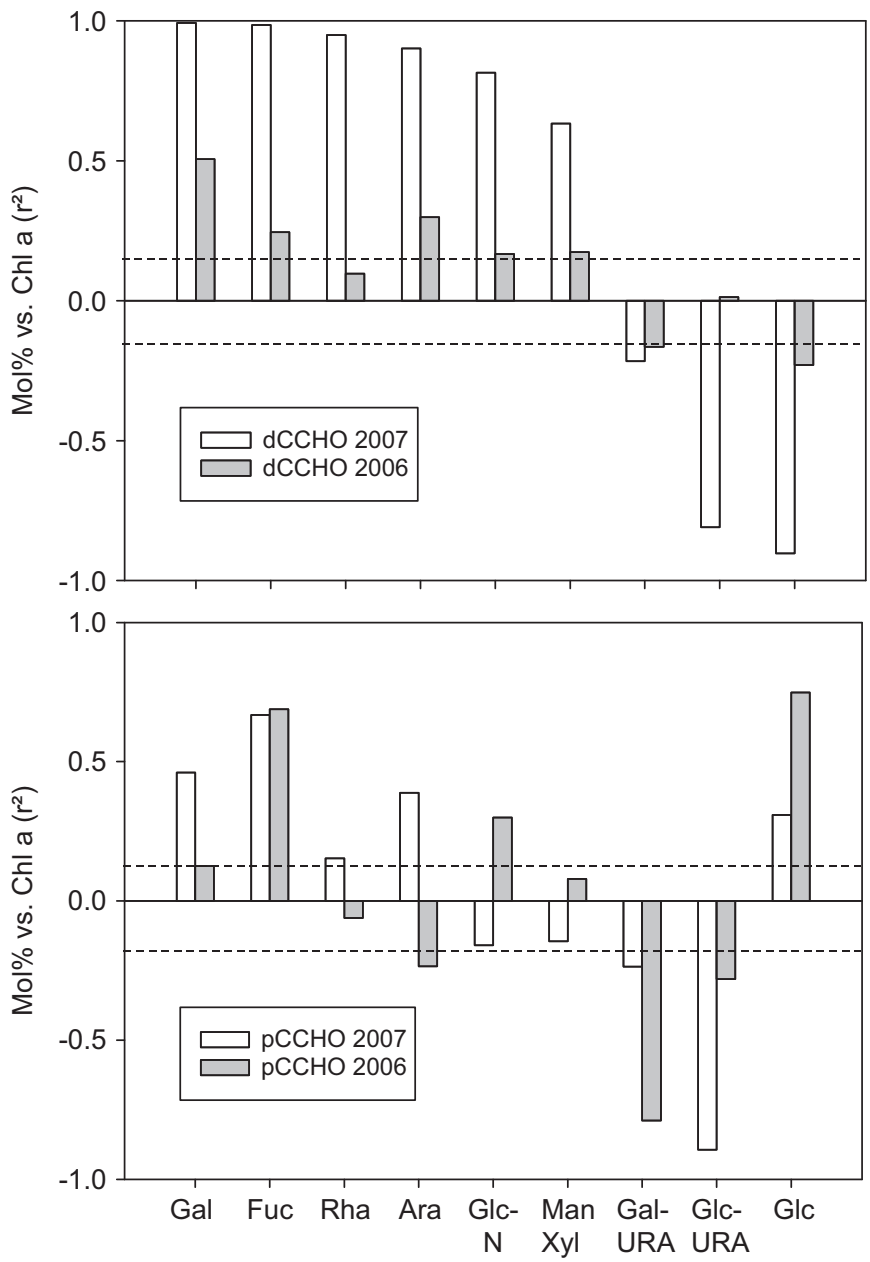

Fig. 5. Coefficients of the correlation $\left(r^{2}\right)$ between chlorophyll- $a$ and the molar percentages of individual sugars contained in HMW-dCCHO and in pCCHO during 2006. For each sugar and fraction, $n=62$. Values of $r^{2}$ between the dash lines were not significant $(p>0.05)$

i.e. POC:TOC (\%), was relatively low throughout the water column, as expected for a post-bloom system, where larger phytoplankton, particularly diatoms, were removed either by sinking or zooplankton grazing. The situation in 2007 was also characterised by a relatively high fraction of polysaccharide-rich gel particles, i.e. TEP (TEP-C:POC), which has been observed for post diatombloom systems in the past (Mari and Burd, 1998). In general, the fraction of POC identifiable as pCCHO was higher in the postdiatom bloom phase, compared to the later situation encountered in 2006 and increased with depth. This may point to compositional changes of POM during degradation and is in accordance with the assumption that carbohydrates are less labile than other biochemical constituents (Wakeham et al., 1997).

DOM contains a high share of older and more refractory substances that escape biochemical analysis. Therefore, it has been suggested that a larger fraction of identifiable bio-molecules is indicative for freshly produced organic matter (Skoog and Benner, 1997; Kaiser and Benner, 2009; Goldberg et al. 2009). Thus, the relatively low fraction of organic carbon characterised as HMW-dCCHO during the post-diatom bloom situation in 2007 suggests that the organic material already underwent substantial microbial degradation as well. Another explanation is the removal of HMW-dCCHO by formation of TEP, supported by the inverse correlation of HMW-dURA and TEP in 2007. The sinking of TEP 
together with diatoms in aggregates may also contribute to the observed increase of pCCHO with depth in 2007.

During the later-in-season cruise in 2006, higher Chl- $a$ concentrations were observed and indicated, together with microscopic and satellite information, the partial prevalence of a coccolithophore bloom (Harlay et al., 2009). The coccolithophore bloom resulted in a new build-up of POC, although TOC concentration was comparable to the situation in 2007. Besides new accumulation of POC, higher concentrations of CCHO were observed during the field investigation in 2006, within particulate fraction and even more pronounced in the HMW-DOM. The HMW-dCCHO yield in DOC was twice as high compared to the post-diatom bloom situation in 2007, suggesting that the second, cocolithophore dominated, bloom could constitute an important source for fresh and carbohydrate-rich DOC in the Bay of Biscay. In general, DOC concentrations observed during 2006 agree well with earlier findings provided within the framework of the OMEX project by Hydes et al. (2001). These authors determined average DOC concentrations of $52 \pm 4,68 \pm 11$ and $51 \pm 6 \mu \mathrm{mol} \mathrm{L}^{-1}$ for the winter, spring and summer season (1993-1995), respectively. We determined minimum DOC concentration of $46 \mu \mathrm{mol} \mathrm{L}^{-1}$ in 2007 and $48 \mu \mathrm{mol} \mathrm{L}^{-1}$ in 2007. Combining information given in Hydes et al. (2001) with our data suggests a background and hence refractory DOC concentration in the Bay of Biscay of about $50 \mu \mathrm{mol} \mathrm{L}^{-1}$. Thus accumulation of new DOC during the winter to spring (post-bloom) transition accounted for an additional $30 \mu \mathrm{mol} \mathrm{L}^{-1}$ in the upper surface layer above the background level. In 2007, even higher DOC concentrations were observed, suggesting that the seasonal DOC accumulation in the surface mixed layer could be as high as $50 \mu \mathrm{mol} \mathrm{L}^{-1}$ above the background level. Thus, seasonal DOC accumulation in the surface mixed layer was similar or even higher than POC concentration after the spring bloom in the Bay of Biscay during both 2006 and 2007.

\subsection{Contribution of $\mathrm{CCHO}$ to $\mathrm{DOC}$ and $\mathrm{POC}$}

Concentrations of $\mathrm{CCHO}$ and HMW-dCCHO determined for the Bay of Biscay during this study $\left(0.6-2.1 \mu \mathrm{mol} \mathrm{L} \mathrm{L}^{-1}\right)$ agreed well with earlier reports on sugar concentration observed for the North Sea $\left(0.3-2.0 \mu \mathrm{mol} \mathrm{L}^{-1}\right)$ (Ittekot et al., 1981). Values for carbohydrate concentration, however, strongly depend on the type of analysis. Bulk carbohydrate methods often yield higher concentrations than those determining individual standard sugars (Panagiotopoulos and Sempéré, 2005). Clearly, a better comparison is achieved with data that were obtained with the same type of analysis. For HPAEC-PAD, most investigations are restricted to neutral and amino sugars, and only few studies have been conducted at coastal or shelf sea sites. For Oregon inshore waters, Borch and Kirchman (1997) determined a neutral sugar concentration of $2.16 \mu \mathrm{mol} \mathrm{L}^{-1}$ including low- and high-molecularweight dCCHO. In contrast, combined neutral sugar concentrations as determined with HPAEC-PAD at open ocean sites are typically $<1 \mu \mathrm{mol} \mathrm{L}^{-1}$ (Panagiotopoulos and Sempéré, 2005; Kaiser and Benner, 2009).

For the Bay of Biscay, the percentage of carbon contained in HMW-dCCHO after the spring bloom determined in this study varied between $4 \%$ and $11 \%$ of DOC. If we assume that in the Bay of Biscay, surface winter HMW-dCCHO concentrations are similar to the minimum HMW-dCCHO concentration observed below the seasonal thermocline, i.e. $4 \mu \mathrm{mol} \mathrm{CL^{-1 }}$, HMW-dCCHO could account for about 13\% of fresh DOC; assuming a minimum seasonal DOC accumulation of $30 \mu \mathrm{mol} \mathrm{L}^{-1}$ as estimated above. Kaiser and Benner (2009) observed that HMW-dCCHO ranged between $2 \%$ and $4 \%$ of DOC in surface waters $(<80 \mathrm{~m}$ ) at the open ocean sites of HOT and BATS, but these values only include neutral sugars. Engel et al. (2011) determined that HMW-dCCHO produced during a fertilised diatom bloom in a mesocosm experiment made up about $24 \%$ of DOC. Comparing these studies thus suggests that the carbon yield of HMW-dCCHO in marine systems is likely to increase with increasing productivity. The pCCHO determined during this study ranged between 7\% and 30\% of POC above the mixed layer. These results agree very well with the findings of Suárez and Marañon (2003), who showed that the carbon fraction of fresh photosynthesates included in particulate polysaccharides varied between $10 \%$ and $30 \%$ over an annual cycle in the southern Bay of Biscay, with maximum values observed during the spring season. In general, our study showed that DOM included a higher fraction of $\mathrm{CCHO}$ than POM during both years, underlining again the importance of DOC for carbon cycling in post-bloom systems.

We estimated that TEP contributed between $40 \%$ and $60 \% \mathrm{OC}$ to pCCHO in the Bay of Biscay after the spring-bloom. These data suggest that TEP formation represents an important way of repartition of carbohydrates from the dissolved into the particulate pool. The \%CCHO yield of TEP was higher in 2007 than in 2006, when fresh CCHO were supplied to the system by the coccolithophores. This suggests that CCHO included in TEP are more refractory than fresh HMW-dCCHO, and may stay in the water column for an extended time, unless included in settling aggregates. It has often been observed that TEP are heavily colonised by microorganisms and represent hot-spots of microbial activity (Simon et al., 2002; Godoi et al., 2009). Thus, TEP are likely to provide important microhabitats for the evolving microbial loop community in shelf-seas like the Bay of Biscay.

\subsection{Compositional changes in $\mathrm{CCHO}$}

During both cruises, data collected for the molar composition of neutral CCHO showed that Glc was the dominant sugar of HMW-dCCHO and pCCHO, followed by Man/Xyl, Gal, Rha and Fuc in slightly changing order between years and depths. Therewith, the molecular composition of CCHO in the Bay of Biscay is generally similar to other coastal and open ocean marine sites (Panagiotopoulos and Sempéré, 2005; Kaiser and Benner, 2009; Goldberg et al., 2009). It has been suggested that the composition of $\mathrm{CCHO}$ can be used to identify the diagenetic alteration of organic matter (Goldberg et al., 2009, 2010), although some studies showed that the molar composition of CCHO can be remarkably stable in marine systems (Borch and Kirchmann, 1997). During this study, depth dependent variations were identified for the molar composition of CCHO. The neutral sugars Fuc, Gal, Rha, and to a lesser extent also Ara were relatively enriched towards surface waters and best correlated with Chl-a, suggesting that these sugars are more labile and indicative of recent production of photosynthesates. Glc on the other hand was enriched below the seasonal thermocline.

These findings are in accordance with observations of Goldberg et al. (2010), made during a north-south transect across the North Atlantic Ocean $\left(50^{\circ} \mathrm{W}\right)$ as well as with experimental data on the diagenetic changes in $\mathrm{CCHO}$ composition during bacterial decomposition gained by Giroldo et al. (2005). Goldberg et al. (2010) observed a decrease of \%Mol of Man/Xyl below $100 \mathrm{~m}$ and concluded that Man/Xyl can be used to identify 'recently' $(<7$ years) accumulated DOC. During our study Man/Xyl did not show this high sensitivity, but our dataset covered only the late spring/ early summer season and only few data were obtained for depths $>100 \mathrm{~m}$. Giroldo et al. (2005) studied the decline in neutral sugars combined within extracellular polysaccharides ( $>12 \mathrm{kDa}$ ) of a freshwater cryptophyte during decomposition by a natural bacterial community. They observed that the decay rates of monosaccharides from exopolymer substances (EPS) over a 
period of 40 days decreased in the order Gal $>$ Fuc $>$ Man/ $\mathrm{Xyl}>\mathrm{Rha}>\mathrm{Glc}$. Hence, despite the different temporal and spatial scales of data coverage, this study supports the findings of Goldberg et al. (2010) and Giroldo et al. (2005), and show consistent diagentic changes in carbohydrate composition during decomposition. Gal appears to be the most labile and Glc the most refractory neutral sugar. Man/Xyl seems to be of intermediate lability with a turnover time potentially too long to reflect seasonal changes within the upper water column. These findings therefore suggest that the composition of combined sugars is principally suited to identify diagenetic changes of organic matter in the water column over periods from weeks to several years. However, the absolute rate of CCHO decomposition also depends on the activity of the heterotrophic microbial populations. For the 2006 and 2007 cruises to the Bay of Biscay, Piontek et al. (2011) estimated a potential turnover time of 170 days for combined glucose in the upper mixed water column, and a much slower turnover below. They determined a faster decomposition of nitrogenous substances, such as proteins and small peptides, and suggested that the bacterial incorporation of sugars might be limited by the availability of inorganic nitrogen at this time of the year.

The uronic acids Gal-URA and Glc-URA were firstly determined for the Bay of Biscay during this study and comprised a relatively large fraction of CCHO. During both years, URA were more evenly distributed over depth than the labile combined neutral sugars. Particularly, a close correlation was observed for Glc and Glc-URA. Surprisingly, little correlation was observed between URA and TEP during both cruises, although Gal-URA correlated with TEP during 2006. However, as both Gal-URA and TEP are produced during coccolithophore growth (Fichtinger-Shepman et al., 1979; Borchard and Engel, 2012), a higher \%Mol of Gal-URA does not necessarily indicate a higher \%Mol of Gal-URA included in TEP. It may also point to a co-occurrence of both substances in seawater. In 2007, higher TEP concentrations were observed, when Glc-URA was generally more abundant than in 2006. Glc-URA is a typical component of water-soluble, mucoid polysaccharides and can be produced by algal as well as by bacterial cells (Leppard, 1995; Tomshich et al., 2007). Glc-URA comprises a significant fraction of algal acidic EPS (47 Mol \%) (Giroldo et al., 2005) and has been suggested to play an important role in TEP formation during diatoms blooms (Engel et al., 2011). Our data therefore suggest that TEP in seawater are of different composition, with TEP produced by coccolithophore potentially having a higher \%Mol of Gal-URA, while those produced by diatoms being possibly more enriched in Glc-URA. It has been estimated that the carbon fraction of TEP, determined colorimetrically based on the adsorption of Alcian Blue to acidic sugars, varies between 39\% and 88\% (weight carbon/Xanthan equivalent weight of TEP) for different phytoplankton species (Engel and Passow, 2001; Engel et al., 2004). This suggests that a significant fraction of TEP is composed of non-acidic sugars, or even of biochemicals other than sugars, as supported by the strong correlation of TEP with the neutral sugars as observed in this and previous studies (Skoog et al., 2008).

\section{Acknowledgements}

The authors would like to thank the officers and crewmembers of the R.V. Belgica for their assistance during the cruises conducted in the northern Bay of Biscay. J. Backers, J.-P. De Blauw and G. Deschepper of the Unit of the North Sea Mathematical Models (Brussels/Oostende, Belgium) are acknowledged for their logistic support in data acquisition. This study was financed by the Helmholtz Association (Contract no. HZ-NG-102), by the Belgian Federal Science Policy Office in the framework of the
PEACE Project (Contract numbers SD/CS/03A\&B) and by the EU FP6 IP CarboOcean project (Contract no. 511176-2). We express also our thanks to C. De Bodt, N. Händel, C. Borchard, T. Mattfeldt and G. Langer for assistance in chemical analyses and for their help in sampling during the two cruises. This is also a contribution to the SOLAS international research initiative.

\section{References}

Alldredge, A.L., Passow, U., Logan, B.E., 1993. The abundance and significance of a class of large, transparent organic particles in the ocean. Deep-Sea Research 40, 1131-1140.

Aluwihare, L.I., Repeta, D.J., Chen, R.F., 1997. A major biopolymeric component to dissolved organic carbon in surface sea water. Nature 387, 166-169.

Anderson, T.R., Williams, P.J. leB., 1999. A one dimensional model of dissolved organic carbon cycling in the water column incorporating combined biological-photochemical decomposition. Global Biogeochemal Cycles 13 337-349.

Arnosti, C., 2004. Speed bumps and barricades in the carbon cycle: substrate structural effects on carbon cycling. Marine Chemistry 92 (1-4), 263-273.

Azam, F., Fenchel, T., Field, J.G., Gray, J.S., Meyer-Reil, L.A., Thingstad, F., 1983. The ecological role of water column microbes in the sea. Marine Ecology Progress Series 10, 257-263.

Azam, F., Hodson, R.E., 1977. Size distribution and activity of marine microheterotrophs. Limnology and Oceanography 22, 492-501.

Benner, R., Pakulski, J.D., McCarthy, M., Hedges, J.I., Hatcher, P.G., 1992. Bulk chemical characterization of dissolved organic matter in the ocean. Science 255, 1561-1564.

Benner, R., 2002. Chemical composition and reactivity. In: Hansell, D., Carlson, C.A (Eds.), Biogeochemistry of Marine Dissolved Organic Matter. Academic Press.

Benz, R., Bauer, K., 1988. Permeation of hydrophilic molecules through the outer membrane of gram-negative bacteria. European Journal of Biochemistry 176 $1-19$.

Biddanda, B., Benner, R., 1997. Carbon, nitrogen, and carbohydrate fluxes during the production of particulate and dissolved organic matter by marine phytoplankton. Limnology and Oceanography 42, 506-518.

Borch, N.H., Kirchman, D.L., 1997. Concentration and composition of dissolved combined neutral sugars (combined carbohydrates) in seawater determined by HPLC-PAD. Marine Chemistry 57, 85-95.

Borchard, C., Engel, A., 2012. Organic matter exudation by Emiliania huxleyi under simulated future ocean conditions. Biogeosciences Disc. 9, 1199-1236.

Carlson, C.A., 2002. Production and removal processes. In: Hansell, D, Carlson, CA (Eds.), Biogeochemistry of Marine Dissolved Organic Matter. Academic Press.

Cho, B.C., Azam, F., 1988. Major role of bacteria in biogeochemical fluxes in the ocean's interior. Nature 332, 441-443.

Chin, W., Orellana, M.V., Verdugo, P., 1998. Spontaneous assembly of marine dissolved organic matter into polymer gels. Nature 391, 568-572.

Copping, A.E., Lorenzen, C.J., 1980. Carbon budget of marine phytoplanktonherbivore system with carbon-14 as tracer. Limnology and Oceanography $25,873-882$.

Decho, A.W., 1990. Microbial exopolymer secretions in the ocean environments their role(s) in food webs and marine processes. Oceanography and Marine Biology Annual Reviews 28, 73-153.

Engel, A., Passow, U., 2001. Carbon and nitrogen content of transparent exopolymer particles (TEP) in relation to their Alcian Blue adsorption. Marine Ecology Progress Series 219, 1-10.

Engel, A., Thoms, S., Riebesell, U., Rochelle-Newall, E., Zondervan, I., 2004 Polysaccharide aggregation as a potential sink of marine dissolved organic carbon. Nature 428, 929-932.

Engel, A., 2009. In: Oliver Wurl Boca Raton [u.a.] (Ed.), Determination of Marine Gel Particles, Practical Guidelines for the Analysis of Seawater. CRC Press, pp. 125-142.

Engel, A., Händel, N., Wohlers, J., Lunau, M., Grossart, H.-P., Sommer, U., Riebesell, U., 2011. Effects of sea surface warming on the production and composition of dissolved organic matter during phytoplankton blooms: results from a mesocosm study. Journal of Plankton Research 33 (3), 357-372.

Engel, A., Händel, N., 2011. A novel protocol for determining the concentration and composition of sugars in particulate and in high molecular weight dissolved organic matter (HMW-DOM) in seawater. Marine Chemistry 127, 180-191.

Fogg, G.E., 1966. The extracellular products of algae. Marine Biology Annual Review 4, 195-212.

Fichtinger-Schepman, A.M., Kamerling, J.P., Vliegenthart, J.F.G., de Jong, E.W., Bosc, L., Westbroek, P., 1979. Composition of a methylated, acidic polysaccharide associated with coccoliths of Emiliania huxleyi (Lohmann) Kamptner. Carbohydrate Research 69, 181-189.

Fuhrman, J.A., 1999. Marine viruses and their biogeochemical and ecologica effects. Nature 399, 541-548.

Giroldo, D., Vieira, A.A.H., Paulsen, B.S., 2005. Extracellular polysaccharides produced by a tropical cryptophyte as a carbon source for natural bacterial populations. European Journal of Phycology 40 (3), 241-249.

Godoi, R.H.M., Aerts, K., Harlay, J., Kaegi, R., Ro, Chul-Un, Chou, L., Van Grieken, R., 2009. Organic surface coating on Coccolithophores-Emiliania huxleyi: its 
determination and implication in the marine carbon cycle. Microchemical Journal 91, 266-271, http://dx.doi.org/10.1016/j.microc.2008.12.009.

Goldberg, S.J., Carlson, C.A., Hansell, D.A., Nelson, N.B., Siegel, D.A., 2009. Temporal dynamics of dissolved combined neutral sugars and the quality of dissolved organic matter in the Northwestern Sargasso Sea. Deep-Sea Research I 56, $672-685$.

Guo, L., Hung, C.C., Santschi, P.H., Walsh, I.D., 2002. ${ }^{234}$ Th scavenging and its relationship to acid polysaccharide abundance in the Gulf of Mexico. Marine Chemistry 78, 103-119.

Hansell, D.A., 2002. DOC in the global ocean carbon cycle. In: Hansell, D.A., Carlson, C.A. (Eds.), Biogeochemistry of Marine Dissolved Organic Matter. Academic Press, San Diego, pp. 685-715.

Hansell, D.A., Carlson, C.A., Repeta, J.D., Schlitzer, R., 2009. Dissolved organic matter in the ocean. A controversy stimulates new insights. Oceanography 22 , 202-211.

Harlay, J., De Bodt, C., Engel, A., Jansen, S., d'Hoop, Q., Piontek, J., Van Oostende, N. Groom, S., Sabbe, K., Chou, L., 2009. Abundance and size distribution of transparent exopolymer particles (TEP) in a coccolithophorid bloom in the northern Bay of Biscay. Deep-Sea Research I 56, 1251-1265.

Harlay, J., Chou, L., De Bodt, C., Van Oostende, N., Piontek, J. Suykens, K., Engel, A. Sabbe, K, Groom, S., Delille, B., Borges, A.V., 2010. Biogeochemistry and carbon mass balance of a coccolithophore bloom in the northern Bay of Biscay (June 2006). Deep-Sea Research I 58, 111-127.

Hopkinson, C.S., Vallino, J.J., 2005. Efficient export of carbon to the deep ocean through dissolved organic matter. Nature 433, 142-145.

Hydes, D.J., Le Gall, A.C., Miller, A.E.J., et al., 2001. Supply and demand of nutrients and dissolved organic matter at and across the NW European shelf break in relation to hydrography and biogeochemical activity. Deep-Sea Research II 48 (14-15), 3023-3047.

Ittekkot, V., Brockmann, U., Michaelis, W., Degens, E.T., 1981. Dissolved Free and Combined Carbohydrates during a Phytoplankton Bloom in the Northern North Sea. Marine Ecology Progress Series 4, 299-305.

Jiao, N., Herndl, G.J., Hansell, D.A., et al., 2010. Microbial production of recalcitrant dissolved organic matter: long-term carbon storage in the global ocean. Nature Reviews Microbiology 8, 593-599.

Kaiser, K., Benner, R., 2009. Biochemical composition and size distribution of organic matter at the Pacific and Atlantic time series stations. Marine Chemistry $119,63-77$

Keir, R.S., Rehder, G., Frankignoulle, M., 2001. Partial pressure and air-sea flux of $\mathrm{CO}_{2}$ in the Northeast Atlantic during September 1995. Deep-Sea Research II 48 (14-15), 3179-3189.

Kirchman, D.L., Meon, B., Ducklow, H.W., Carlson, C.A., Hansell, D.A., Steward, G.F., 2001. Glucose fluxes and concentrations of dissolved combined neutral sugars (polysaccharides) in the Ross Sea and Polar Front Zone, Antarctica. Deep Sea Research Part II, Topical Studies in Oceanography 48 (19-20), 4179-4197.

Leppard, G.G., 1995. The characterization of algal and microbial mucilage's and their aggregates in aquatic ecosystems. Science of the Total Environment 165, 103-131.

Mann, K.H., Lazier, J.R.N., 1991. Dynamics of Marine Ecosystems. BiologicalPhysical Interactions in the Oceans. Blackwell Scientific Publications, Cambridge $466 \mathrm{pp}$

Mari, X., Burd, A., 1998. Seasonal size spectra of transparent exopolymeric particles (TEP) in a coastal sea and comparison with those predicted using coagulation theory. Marine Ecology Progress Series 163, 63-76.

Mari, X., 1999. Carbon content and C:N ratio of transparent exopolymeric particles (TEP) produced by bubbling exudates of diatoms. Marine Ecology Progress Series 183, 59-71.

Mopper, K., Zhou, J., Ramana, K.S., Passow, U., Dam, H.G., Drapeau, D.T., 1995. The role of surface-active carbohydrates in the flocculation of a diatom bloom in mesocosm. Deep-Sea Research II 42, 47-73.

Myklestad, S., 1977. Production of carbohydrates by marine planktonic diatoms. I Influence of the N/P ratio in the growth medium on the assimilation ratio, growth rate and production of cellular and extracellular carbohydrates by Chaetoceros affinis var Willei (Gran) Hustedt and Skeletonema costatum (Grev) Cleve. Journal of Experimental Marine Biology and Ecology 29, 161-179.
Nagata, T., 2000. Production mechanisms of dissolved matter. In: Kirchmann, D.L. (Ed.), Microbial Ecology of the Oceans. Wiley-Liss, New York, pp. 121-152.

Ogawa, H., Amagai, Y., Koike, I., Kaiser, K., Benner, R., 2001. Production of refractory dissolved organic matter by bacteria. Science 292, 917-920.

Pakulski, J.D., Benner, R., 1994. Abundance and distribution of carbohydrates in the ocean. Limnology and Oceanography 39, 930-940.

Panagiotopoulos, C., Sempéré, R., 2005. Analytical methods for the determination of sugars in marine samples, a historical perspective and future directions. Limnology and Oceanography Methods 3, 419-453.

Parsons, T.R., Takahashi, M., Hargrave, B., 1983. Biological Oceanographic Processes, third ed. Pergamon Press, Oxford, UK.

Passow, U., 2002. Transparent exopolymer particles (TEP) in aquatic environments. Progress in Oceanography 55, 287-333.

Piontek, J., Händel, N., de Bodt, C., Harlay, J., Chou, L., Engel, A., 2011. The utilization of polysaccharides by heterotrophic bacterioplankton in the Bay of Biscay (North Atlantic Ocean). Journal of Plankton Research 33, 1719-1735.

Qian, J., Mopper, K., 1996. An automated, high performance, high temperature combustion dissolved organic carbon analyzer. Analytical Chemistry 68, 3090-3097.

Quigley, M.S., Santschi, P.H., Hung, C.-C., Guo, L., Honeyman, B.D., 2002. Importance of acid polysaccharides for 234Th complexation to marine organic matter. Limnology and Oceanography 47, 367-377.

Ramus, J., 1977. Alcian Blue, a quantitative aqueous assay for algal acid and sulfated polysaccharides. Journal of Phycology 13, 345-348.

Skoog, A., Benner, R., 1997. Aldoses in various size fractions of marine organic matter, implications for carbon cycling. Limnology and Oceanography 42, 1803-1813.

Skoog, A., Alldredge, A., Passow, U., Dunne, J., Murray, J., 2008. Neutral aldoses as source indicators for marine snow. Marine Chemistry 108, 195-206.

Simon, M, Grossart, HP, Schweitzer, B, et al., 2002. Microbial ecology of organic aggregates in aquatic ecosystems. Aquatic Microbial Ecology 28 (2), 175-211.

Smith, D.C., Simon, M., Alldredge, A.L., Azam, F., 1992. Intense hydrolytic enzyme activity on marine aggregates and implications for rapid particle dissolution. Nature 359, 139-142.

Steigenberger, S., Statham, P.J., Voelker, C., Passow, U., 2010. The role of polysaccharides and diatom exudates in the redox cycling of $\mathrm{Fe}$ and the photoproduction of hydrogen peroxide in coastal seawaters. Biogeosciences 7 (1), 109-119.

Strom, S.L., Benner, R., Ziegler, S., Dagg, M.J., 1997. Planktonic grazers are a potentially important source of marine dissolved organic carbon. Limnology and Oceanography 42 (6), 1364-1374.

Suárez, I., Marañon, E., 2003. Photosynthate allocation in a temperate sea over an annual cycle, the relationship between protein synthesis and phytoplankton physiological state. Journal of Sea Research 50, 285-299.

Tomshich, S.V., Komandrova, N.A., Widmalm, G, Nedashkovskaya, O.I., Shashkov, A.S., Perepelov, A.V., 2007. Structure of acidic o-specific polysaccharide from the marine bacterium Cellulophaga baltica. Russian Journal of Bioorganic Chemistry 33 (1), 83-87.

van Oostende, N., Harlay, J., Vanelslander, B., Chou, L., Sabbe, K. Phytoplankton community dynamics during late spring coccolithophore blooms at the continental margin of the Celtic Sea (North East Atlantic, 2006-2008). Progress in Oceanography, forthcoming.

Verdugo, P., Santschi, P.H., 2010. Polymer dynamics of DOC networks and gel formation in seawater. Deep-Sea Research II 57 (16), 1486-1493.

Wakeham, S.G., Lee, C., Hedges, J.I., Hernes, P.J., Peterson, M.L., 1997. Molecular indicators of diagenetic status in marine organic matter. Geochimica et Cosmochimica Acta 61, 5363-5369.

Weiss, M.S., Abele, U., Weckesser, J., Welte, W., Schiltz, E., Schulz, G.E., 1991. Molecular architecture and electrostatic properties of a bacterial porin. Science 254, 1627-1630.

Yentsch, C.S., Menzel, D.W., 1963. A method for the determination of phytoplankton chlorophyll and phaeophytin by fluorescence. Deep-Sea Research and Oceanographic Abstracts 10, 221-231.

Zhou, J., Mopper, K., Passow, U., 1998. The role of surface active carbohydrates in the formation of transparent exopolymer particles by bubble adsorption of seawater. Limnology and Oceanography 43, 1860-1871. 